\title{
Present Status and Future Management Strategies for Sugarcane Yellow Leaf Virus: A Major Constraint to the Global Sugarcane Production
}

\author{
Somnath Kadappa Holkar (iD) 1ंథ*, Parameswari Balasubramaniam ${ }^{2 \dagger}$, Atul Kumar ${ }^{1,3}$, Nithya Kadirvel ${ }^{4}$, \\ Prashant Raghunath Shingote ${ }^{5}$, Manohar Lal Chhabra ${ }^{2}$, Shubham Kumar ${ }^{2}$, Praveen Kumar ${ }^{2}$, \\ Rasappa Viswanathan ${ }^{4}$, Rakesh Kumar Jain ${ }^{6}$, and Ashwini Dutt Pathak ${ }^{7}$ \\ ${ }^{1}$ ICAR-Indian Institute of Sugarcane Research, Biological Control Centre, Pravaranagar, Maharashtra 413 712, India \\ ${ }^{2}$ ICAR-Sugarcane Breeding Institute, Regional Centre, Karnal, Haryana 132 001, India \\ ${ }^{3}$ Amity Institute of Biotechnology, Amity University, Lucknow Campus, Lucknow 226 010, Uttar Pradesh, India \\ ${ }^{4}$ Division of Crop Protection, ICAR-Sugarcane Breeding Institute, Coimbatore 641 007, Tamil Nadu, India \\ ${ }^{5}$ Vasantrao Naik College of Agricultural Biotechnology (Dr. PDKV, Akola), Yawatmal 445001, Maharashtra, India \\ ${ }^{6}$ Division of Plant Pathology, ICAR-Indian Agricultural Research Institute, Pusa Campus, New Delhi 110 012, India \\ ${ }^{7}$ ICAR-Indian Institute of Sugarcane Research, Lucknow 226 002, Uttar Pradesh, India

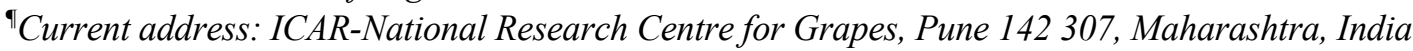

(Received on September 17, 2020; Revised on October 23, 2020; Accepted on November 7, 2020)

Sugarcane yellow leaf virus (SCYLV) is a distinct member of the Polerovirus genus of the Luteoviridae family. SCYLV is the major limitation to sugarcane production worldwide and presently occurring in most of the sugarcane growing countries. SCYLV having high genetic diversity within the species and presently ten genotypes are known to occur based on the complete genome sequence information. SCYLV is present in almost all the states of India where sugarcane is grown. Virion comprises of 180 coat protein units and are $24-29 \mathrm{~nm}$ in diameter. The genome of SCYLV is a monopartite and comprised of single-stranded (ss) positive-sense $(+)$ linear RNA of about $6 \mathrm{~kb}$ in size. Virus genome consists of six open reading frames (ORFs) that are expressed by sub-genomic RNAs. The SCYLV is phloem-limited and transmitted by sugarcane aphid Melanaphis sacchari in

\footnotetext{
${ }^{\dagger}$ These authors contributed equally to this work.

*Corresponding author.

Phone) +91-7355086348, FAX) +91-20-2695-6099

E-mail) somnathbhu@gmail.com

ORCID

Somnath Kadappa Holkar

https://orcid.org/0000-0001-9197-8765

(c) This is an Open Access article distributed under the terms of the Creative Commons Attribution Non-Commercial License (http:// creativecommons.org/licenses/by-nc/4.0) which permits unrestricted noncommercial use, distribution, and reproduction in any medium, provided the original work is properly cited.
}

Articles can be freely viewed online at www.ppjonline.org. a circulative and non-propagative manner. The other aphid species namely, Ceratovacuna lanigera, Rhopalosiphum rufiabdominalis, and $R$. maidis also been reported to transmit the virus. The virus is not transmitted mechanically, therefore, its transmission by M. sacchari has been studied in different countries. SCYLV has a limited natural host range and mainly infect sugarcane (Sachharum hybrid), grain sorghum (Sorghum bicolor), and Columbus grass (Sorghum almum). Recent insights in the protein-protein interactions of Polerovirus through protein interaction reporter (PIR) technology enable us to understand viral encoded proteins during virus replication, assembly, plant defence mechanism, short and long-distance travel of the virus. This review presents the recent understandings on virus biology, diagnosis, genetic diversity, virus-vector and host-virus interactions and conventional and next generation management approaches.

Keywords : evolution, genome organization, integrated disease management, Sugarcane yellow leaf virus

Handling Editor : Ho-Jong Ju

Sugarcane (genus: Saccharum) is a member of the family Poaceae. Sugarcane (Saccharum interspecific hybrids) is considered as the industrially significant crop since it is rich source of bioenergy and by-products. Sugarcane is a 
very useful asset for economic developments in different regions of the globe including India. Sugarcane is grown on 26-million-hectare area in more than 90 countries across the globe. However, sugarcane production is more challenging because this crop is affected by several pathogens and other factors (Birchfield, 1984; Ricaud et al., 2012; Rott et al., 2000). Among the biotic stresses, sugarcane is infected by different virus species viz., Sugarcane yellow leaf virus (SCYLV) inducing yellow leaf disease (YLD), Sugarcane streak virus (SSV) responsible for causing streak disease, Sugarcane Fiji disease virus (SFDV) causing infamous Fiji disease, Sugarcane bacilliform virus (SCBV) known to induce fleck leaf disease (Braithwaite et al., 1995) and Sugarcane streak mosaic virus (SCSMV), and Sugarcane mosaic virus (SCMV) (Rott et al., 2000; Viswanathan and Rao, 2011) are associated with mosaic disease. Among the sugarcane infecting viruses, SCYLV causes YLD in sugarcane in more than 25 countries in the world where sugarcane is widely cultivated (Table 1).

First occurrence of YLD was described in 1988 in Hawaii on sugarcane cv. H 65-7052, which showed severe yellowing throughout the plantation (Schenck, 1990; Schenck et al., 1997). The origin of YLD ways back to 1960s and 1970s, when the disease was defined as yellow leaf syndrome or yellow wilt in Tanzania during 1962 (Ricaud, 1968; Rott et al., 2008). Since then, the disease has spread in all the regions wherever sugarcane is cultivated (Gonçalves et al., 2012). In India, YLD was first recorded in farmer's field in 1999 by Viswanathan et al. (1999) and since then its widespread incidence was reported throughout the country (Rao et al., 2000, 2001; Viswanathan, 2002). During 1990s, one decade after its first record from Hawaii, the extracted virus was confirmed with the diseased plants and recognized as a tentative species of Polerovirus (Scagliusi and Lockhart, 2000; Vega et al. 1997). Members of the genus are known to infect dicots and some of them are restricted to monocot plant species (Hull, 2002). Currently, more than 17 species are known to occur in this genus including Potato leafroll virus (PLRV) (Lefkowitz et al., 2018).

\section{Economic Impact of SCYLV}

The SCYLV has a negative effect on sugarcane yield and yield contributing parameters (Grisham et al., 2001; Izaguirre-Mayoral et al., 2002; Lehrer et al., 2008, 2009; Rassaby et al., 2003; Rott et al., 2008; Smith et al., 2000; Vega et al., 1997; Viswanathan, 2002; Viswanathan and Rao, 2011; Viswanathan et al., 2014, 2016; Yan et al., 2009; Zhou et al., 2006; Zhu et al., 2010). Due to virus infection, yield losses of $15 \%$ and up to $50 \%$ in sugarcane were reported from United States (Lockhart and Cronje, 2000) and Brazil (Vega et al., 1997), respectively. The $50 \%$ was the highest yield loss reported due to SCYLV in ratoon crops (Grisham et al., 2001; Vega et al., 1997). Up to $14 \%$ loss in sugar yield was described in Louisiana (Gonçalves et al., 2005; Grisham et al., 2009). In Florida, 11\% loss was recorded in sugar yield and stalk weight (Comstock and Miller, 2004), $14 \%$ loss in sugar yield (Flynn et al., 2005) and $11 \%$ to $27 \%$ in sugarcane yield were reported in different experimental fields (Boukari et al., 2019). In Reunion of Island, $11 \%$ and $28 \%$ losses were documented in sugar content and stalk weight, respectively due to virus infection (Rassaby et al., 2004). Around 30\% loss in yield was stated in asymptomatic sugarcane plants in Thailand (Lehrer et al., 2008). Therefore, the major challenge before the researchers is to pin-point the infection and devising management strategies.

SCYLV infection has significantly affected the cane growth, stalk number, cane diameter, leaf area, chlorophyll content, sugar transport, and sucrose accumulation in the susceptible sugarcane varieties and lead to the substantial decline in sucrose content, HR brix and number of millable canes (Arocha et al., 1999; Cronje et al., 1998; Grisham et al., 2001; Izaguirre-Mayoral et al., 2002; Scagliusi and Lockhart, 2000; Viswanathan, 2002; Viswanathan et al., 2006, 2008). Moreover, yield loss was also recorded due to mixed infection of SCYLV and Sugarcane yellows phytoplasma (SCYP) (Aljanabi et al., 2001; Parmessur et al., 2002). Rassaby et al. (2003) reported $28 \%$ and $46 \%$ decrease in the stalk weight in plant and ratoon crops, respectively with overall $37 \%$ drop in the cane yield due to infection of SCYLV. During the past few decades of investigation on SCYLV showed that infection was found to have a significant effect on sugarcane interference metabolism of phloem cells (Gonçalves et al., 2012; Lehrer et al., 2008; Schenck and Lehrer, 2000). Lehrer et al. (2009) compared biomass of virus-free and diseased plants and showed $44 \%$ increased stalk numbers in the virus-free plants that led to the $35 \%$ rise in sugar yield when both harvested at 11 months crop age but this scenario changed in sugar yield when crops were harvested in 16 to 24 months due to over maturity stage. Viswanathan et al. (2014) studied the negative effect of SCYLV; reduction in different parameters including $24 \%$ in photosynthetic rate, $28 \%$ in stomatal conductance, $10 \%$ in chlorophyll content, $10 \%$ in chlorophyll-fluorescence ratio, $10 \%$ in length of the internodes, $15 \%$ in girth of the stalk, $28 \%$ in stalk weight, up to $44 \%$ in leaf sheath weight and $39 \%$ in juice yield while, increasing the levels of carbohydrates and transpiration rate 
by $81 \%$ and $16 \%$, respectively in virus infected leaves.

\section{Recognition of Physical Properties, Symptomatol- ogy, and Diagnosis of SCYLV}

Initially, the SCYLV was suggested for its inclusion in the family Luteoviridae (Scagliusi and Lockhart, 2000; Smith et al., 2000; Vega et al., 1997), which later confirmed by Irey et al. (1997). Virions of SCYLV are icosahedral and ranged from 24 to $29 \mathrm{~nm}$ in diameter with a buoyant density of $1.30 \mathrm{~g} / \mathrm{cm}^{3}$ in $\mathrm{Cs}_{2} \mathrm{SO}_{4}$ (Scagliusi and Lockhart, 2000). SCYLV is comprised of positive-sense single-stranded (ss) RNA of about $\sim 6 \mathrm{~kb}$ in size. Molecular weight of coat protein $(\mathrm{CP})$ is $27 \mathrm{kDa}$.

Symptoms of SCYLV on sugarcane were described earlier by various workers (Ahmad et al., 2006a, 2006b, 2007; Bailey et al., 1996; Borth et al., 1994; Comstock et al., 1994, 1998; Fitch et al., 2001; Izaguirre-Mayoral et al.,
2002; Lockhart et al., 1996; Schenk et al., 1997; Vega et al., 1997). In India, Viswanathan et al. (1999) and Viswanathan (2002) first time reported that SCYLV is associated with YLD. The YLD affected sugarcane plants exhibited various symptoms including mild to severe yellowing of the midribs (Fig. 1B and C), smaller and clustering of leaves at the crown region of the plant along with the shortened internodes. Midrib yellowing (Fig. 1D and E), necrosis observed from tip to the base of leaves. Subsequently, complete drying of leaf foliage with stunted and poor growth was observed due to severe incidence of the disease under field situations (Fig. 1F). Natural occurrence of SCYLV was recorded on grain sorghum (Sorghum bicolor) cv. Top76-6 by Elsayed et al. (2018) based on the NCBI GenBank accession numbers (KT960997, KT960996, and KT960995). Similarly, from the United States the natural occurrence of SCYLV on S. bicolor and Columbus grass (Sorghum almum) was identified (Espinoza-Delgado et al.,
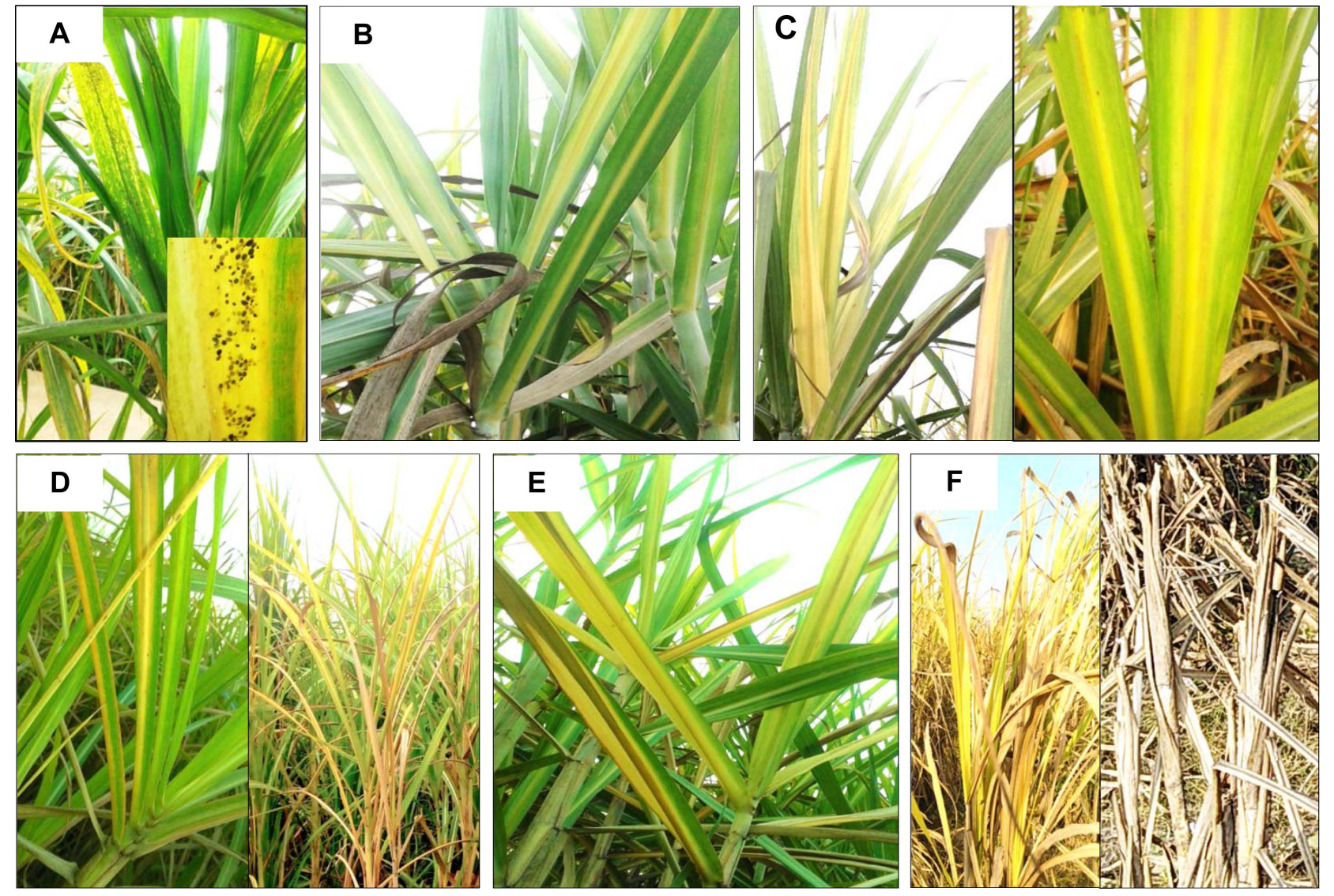

Fig. 1. Symptoms of yellow leaf disease in sugarcane and natural occurrence of aphid colonies; aphid (Melanaphis sacchari) infesting sugarcane and reported vector of Sugarcane yellow leaf virus (SCYLV) in India (A); matured leaves with mild yellowing of midrib (B); young leaves showing mild midrib yellowing and matured leaves showing initial discoloration of leaf lamina (C); young leaves showing bright midrib yellowing and matured leaves showing extensive discoloration of lamina with necrosis (D); severe necrosis of leaf area in matured leaves (E) and plant showed extensive stunting with complete drying $(\mathrm{F})$. 
2016; Wei et al., 2016).

Occurrence of virions was observed under electron microscopy (EM) and immunosorbent electron microscopy (ISEM) in moderately cleansed sap of YLD affected sugarcane (Madugula and Gali, 2017, 2018; Moutia and Saumtally, 1999; Scagliusi and Lockhart, 2000). The presence of virus was detected by EM combined with serology. EM studies showed the diameter of isometric virus particles ranged from 24 to $26 \mathrm{~nm}$ (Vega et al., 1997). A polyclonal antibody was raised for detection of SCYLV which showed negative reaction against related Luteovirus species viz., Bean leafroll virus (BLRV), Rose spring dwarf-associated virus (RSDaV), Soybean dwarf virus (SbDV), BYDV$P A V, B Y D V$-MAV, BYDV-PAS, BYDV-kerII, BYDV-kerIII by enzyme-linked immunosorbent assay (ELISA) and ISEM (Scagliusi and Lockhart, 2000). In dot immunoblot assays, SCYLV specific antiserum showed cross reaction with BYDV-RPV, due to its biological and serological distinctness from other members of the group (Scagliusi and Lockhart, 2000). Later, tissue blot immuno-assay was developed using the available polyclonal antiserum to detect SCYLV and since then it became a widely used technique for routine virus detection (Chatenet et al., 2001; Comstock and Miller, 2003; Comstock et al., 1998, 1999; Madugula and Gali, 2018; Rassaby et al., 2003; Schenck et al., 1997, Victoria et al., 2005). Moreover, double antibody sandwich (DAS)-ELISA was optimized to detect SCYLV in extract obtained from whole cane, stem and leaf tissues (Madugula and Gali, 2017, 2018; Viswanathan and Balamuralikrishnan, 2004).

Further, reverse transcription-polymerase chain reaction (RT-PCR) and multiplex PCR assays were standardized and detected the presence of SCYLV in the asymptomatic sugarcane plants (Chinnaraja and Viswanathan, 2017; Chinnaraja et al., 2014; Korimbocus et al., 2002; Sharma et al., 2017; Viswanathan et al., 2008, 2009, 2010; Xie et al., 2009; Zhu et al., 2010). Gonçalves et al. (2002) optimized the AmpliDet (RNA) method for SCYLV detection in sugarcane and insect-vector (aphid: Melanaphis sacchari) and accuracy was analyzed with DAS-ELISA, RTPCR and nucleic acid sequence-based amplification assay combined with northern blotting analysis techniques. In India, identification of SCYLV in both symptomatic and asymptomatic plants have been performed by RT-PCR using the virus specific primers (Singh et al., 2009; Viswanathan et al., 2008, 2009, 2010) (Fig. 2A). Higher sensitivity and specificity of real-time quantitative PCR (RT-qPCR), confirmed the association of SCYLV and its quantification in asymptomatic sugarcane plants. Most of the sugarcane varieties infected by SCYLV do not express symptoms under field conditions (Chinnaraja and Viswanathan, 2017; Chinnaraja et al., 2014; Korimbocus et al., 2002; Sharma et al., 2017; Zhu et al., 2010). Recently, reverse transcription loop-mediated isothermal amplification technique detected presence of SCYLV in sugarcane (Amata et al., 2016; Anandakumar et al., 2018; Hodgetts et al., 2011; Nair et al.,

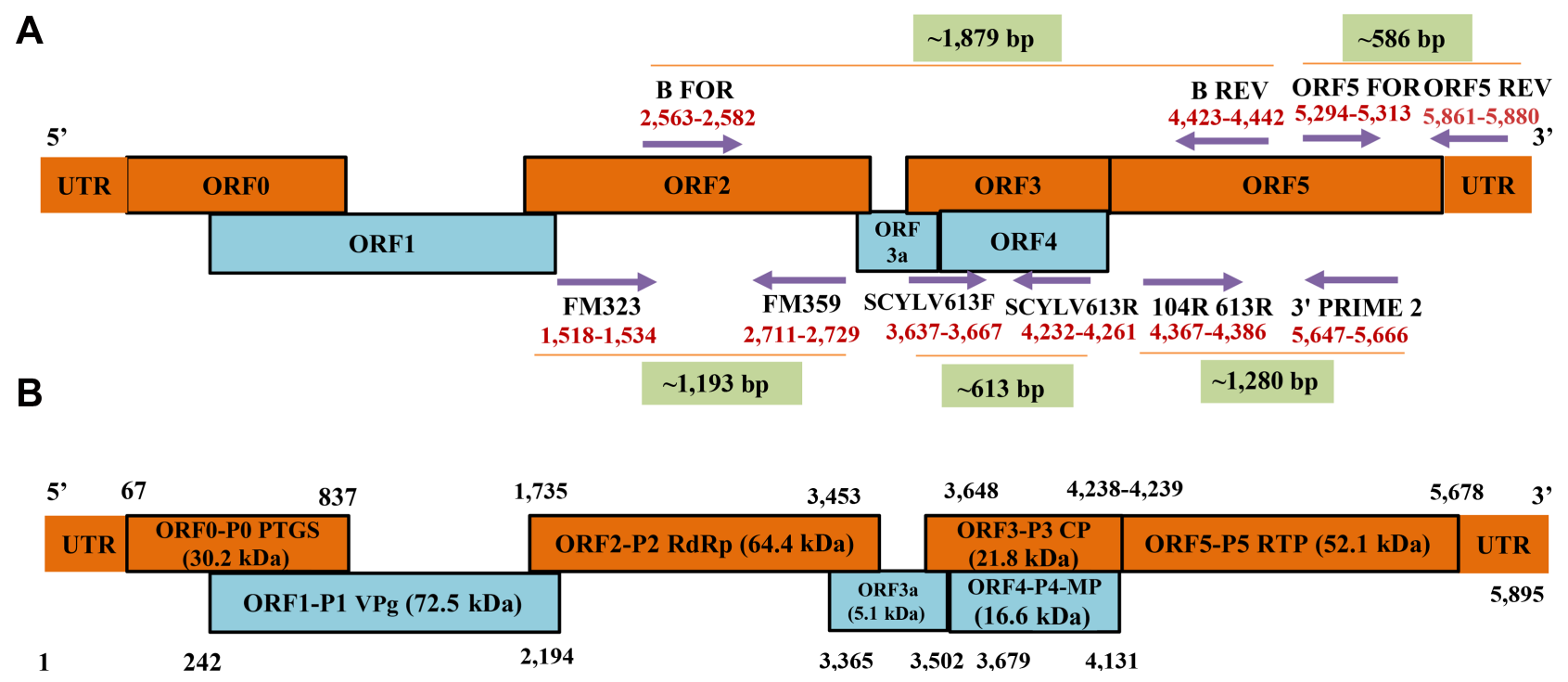

Fig. 2. (A) Schematic representation of the primer positions on Sugarcane yellow leaf virus (SCYLV) genome based on Ahmed et al. (2006a), Moonan and Mirkov (2002), Borg et al. (unpublished), and Viswanathan et al. (2008). (B) Schematic representation of the genome organization of Sugarcane yellow leaf virus (SCYLV) with nucleotide positions of different open reading frames which encoding various proteins and their molecular weight based on first evidence given by Smith et al. (2000). 
2016; Sharma et al., 2017).

\section{The Genome Organization and Expression Strate- gies of SCYLV}

The SCYLV is a positive-sense, ssRNA virus of about $\sim 6$ $\mathrm{kb}$ in size (Moonan et al., 2000). SCYLV genome is composed of six open reading frames (ORFs) viz., ORF0, 1, 2, 3, 4 , and ORF5 with the three 5 '-untranslated regions (Moonan and Mirkov, 2002; Smith et al., 2000). The ORF0 encodes a viral suppressor (P0:30.2 kDa) responsible for RNA silencing mechanism (Ahmad et al., 2006a; Mangwende et al., 2009). ORF1 and ORF2 are translated simultaneously whereas, ORF1 encodes single multifunctional protein (P1:72.5 kDa) while, ORF2 encodes the RNA-dependent RNA polymerase (Smith et al., 2000). ORF3 encodes a viral coat protein $\mathrm{P} 3(\mathrm{CP} ; 21.8 \mathrm{kDa})$, and ORF4 is mainly involved to encode a viral movement protein $(16.6 \mathrm{kDa})$ (Smith et al., 2000). ORF5 is translated by the peptide encoded by ORF3 which act as read-through protein (RTP) by translational read-through process, is known as major component of the virus particle and involved in the virus transmission by aphids $(52.1 \mathrm{kDa})$ (Lockhart et al., 1996; Moonan and Mirkov, 2002; Smith et al., 2000). ORF3 and ORF4 are having distinct characteristics common with several known genotypes (Ahmad et al., 2006a; Zhu et al., 2011). Schematic representation of the genome composition of SCYLV has been shown based on Smith et al. (2000) (Fig. 2B).

The length of SCYLV genome ranged from 5,6125,899 nucleotide (nts) long in all the genotypes originating from different countries. So far, 36 complete genomes of SCYLV isolates have been characterized, of which 33 were from sugarcane and three from sorghum. Of the total 36 virus isolates, seven were from France (Reunion) (Ahmad et al., 2006b; Lin et al., 2014), six each characterized from India (Chinnaraja et al., 2013; Gaur et al., 2003, unpublished and based on NCBI, Genbank database). Five SCYLV isolates were completely characterized from Mauritius (Joomun et al., 2017, unpublished and based only on NCBI Genbank accessions), three were representing from Hawaii (Elsayed et al., 2011), one each representing from Cuba (Ahmad et al., 2017, unpublished and based only on NCBI GenBank accessions), Colombia (Ahmad et al., 2017, unpublished and based only on NCBI Genbank accessions), and Brazil (Ahmad et al., 2006b). The others were from United States (Elsayed et al., 2015; Moonan et al., 2000; Smith et al., 2000) and China (Ahmad et al., 2006b; Gao et al., 2012; Lin et al., 2014; Wang and Zhou et al., 2010; Wang et al., 2012; Zang et al., 2010; unpublished and based only on NCBI Genbank accessions) (Table 1).

Genome expression strategies of the members of Polerovirus involves four mechanisms viz., leaky scanning, subgenomic (Sg) RNAs, and -1 frameshifting (Mayo and Miller, 1999). Read-through strategy of viral genome expression has been documented for the members of $L u$ teoviridae (King et al., 2011). Polerovirus members comprising six ORFs. The 3' ORFs are known to be expressed from the Sg RNAs. Translation of ORF 4 is generally followed by leaky scanning strategy from ORF 3 translation initiation (Dinesh-Kumar and Miller, 1993; Tacke et al., 1990). Serine proteinase are found in members of this genus (Spall et al., 1997). The -1 frameshifting strategy studied in Polerovirus type species i.e., PLRV and found the strongly structured regions which were separated by the spacer region frameshift point and pseudoknots (Giedroc and Cornish, 2009).

Geographical Distribution, Genotypes, and Genetic Diversity of SCYLV

Infection of SCYLV in sugarcane is present in around 25 countries i.e., Germany, Guatemala, India, Colombia, Jamaica, Kenya, Martinique, Malaysia, Brazil, Mauritius, Mexico, China, Papua New Guinea, Peru, Australia, Philippines, Reunion of Islands, Senegal, South Africa, Cuba, Sri Lanka, Taiwan, Tunisia, Argentina, and the United States (Table 1, Fig. 3). In India, YLD is present in different states and adversely affected sugarcane varieties viz., CoC 92061, Co 6304, CoA 05323, CoC 86062, CoV 09356, CoA 92081, CoV 06356, Co 86032, CoV 94102, Co 94012, and CoV 92102 (Rao et al., 2000; Viswanathan, 2002; Viswanathan and Rao, 2011; Viswanathan et al., 1999, 2017b). Since its first record, the prevalence of YLD was reported from 2012-13 to 2019-20 from different states in India (Fig. 3). The existence of disease in Uttar Pradesh of India in different sugarcane genotypes were documented (Holkar et al., 2015, 2016a). Recently, Madugula et al. (2020) has recorded the status of YLD in Andhra Pradesh and Telangana States of India. So far, ten SCYLV genotypes have been documented based on whole genome characterization and designated them as: BRA (Brazil), CHN1, CHN2 and CHN3 (China), CUB (Cuba), HAW (Hawaii), IND (India), PER (Peru), COL (Colombia), and REU (Reunion Island) (Fig. 4A).

Initially, existence of three SCYLV genotypes including REU, BRA, and PER were reported by Ahmad et al. (2006a) and found distributed among eight virus isolates from different countries. In addition to this, another isolate from Cuba, was partially characterized which showed 
Table 1. Distribution of SCYLV isolates based on the complete and partial genome and other ORFs sequence originating from different sugarcane genotypes from different countries including India

\begin{tabular}{|c|c|c|c|c|}
\hline $\begin{array}{l}\text { Sl. } \\
\text { No. }\end{array}$ & Country & $\begin{array}{l}\text { No. of } \\
\text { SCYLV } \\
\text { isolates }\end{array}$ & Variety/Host & Reference \\
\hline \multirow[t]{2}{*}{1} & Argentina & 4 & Q136 (clone) & Moonan et al. (2002) \\
\hline & & & Sugarcane ( $n=3)$ (Saccharum hybrid) & Bertani et al. (2014) \\
\hline 2 & Australia & 8 & VMC71-238 $(n=8)$ & Borg et al. $\left(2002^{a}\right)$ \\
\hline \multirow[t]{6}{*}{3} & Brazil & 19 & RB83-5054, SP71-6163 & Ahmad et al. (2006a, 2006b) \\
\hline & & & SP71-6163 (clone) & Moonan and Mirkov (2002) \\
\hline & & & $\operatorname{SP} 83-5073(n=6)$ & $\begin{array}{l}\text { Borg et al. }\left(2002^{\mathrm{a}}\right) \text {, Rassaby et } \\
\text { al. }\left(2003^{\mathrm{a}}\right)\end{array}$ \\
\hline & & & $\operatorname{SP77-5181~}(n=4)$ & Borg et al. $\left(2002^{\mathrm{a}}\right)$ \\
\hline & & & RB83-5054 & Rassaby et al. $\left(2003^{\mathrm{a}}\right)$ \\
\hline & & & Sugarcane $(n=6)$ (Saccharum hybrid) & $\begin{array}{l}\text { Maia et al. (2000), Rassaby et al. } \\
\left(2003^{\mathrm{a}}\right) \text {, Sawazaki et al. }\left(2011^{\mathrm{a}}\right)\end{array}$ \\
\hline \multirow[t]{4}{*}{4} & Colombia & 9 & CC87-505 & Ahmad et al. $\left(2017^{\mathrm{a}}\right)$ \\
\hline & & & CC84-75(Clone), CC85-964 (clone) & Moonan and Mirkov (2002) \\
\hline & & & $\operatorname{SP} 71-6163(n=5)$ & $\begin{array}{l}\text { Moonan and Mirkov (2002), } \\
\text { Rassaby et al. }\left(2003^{\mathrm{a}}\right)\end{array}$ \\
\hline & & & Sugarcane (Saccharum hybrid) & Rassaby et al. $\left(2003^{\mathrm{a}}\right)$ \\
\hline \multirow[t]{2}{*}{5} & Cuba & 4 & Sugarcane $(n=3)$ (Saccharum hybrid) & Rassaby et al. $\left(2003^{\mathrm{a}}\right)$ \\
\hline & & & $\mathrm{C} 132-81$ & Ahmad et al. (2006a, 2006b) \\
\hline \multirow[t]{9}{*}{6} & China & 109 & 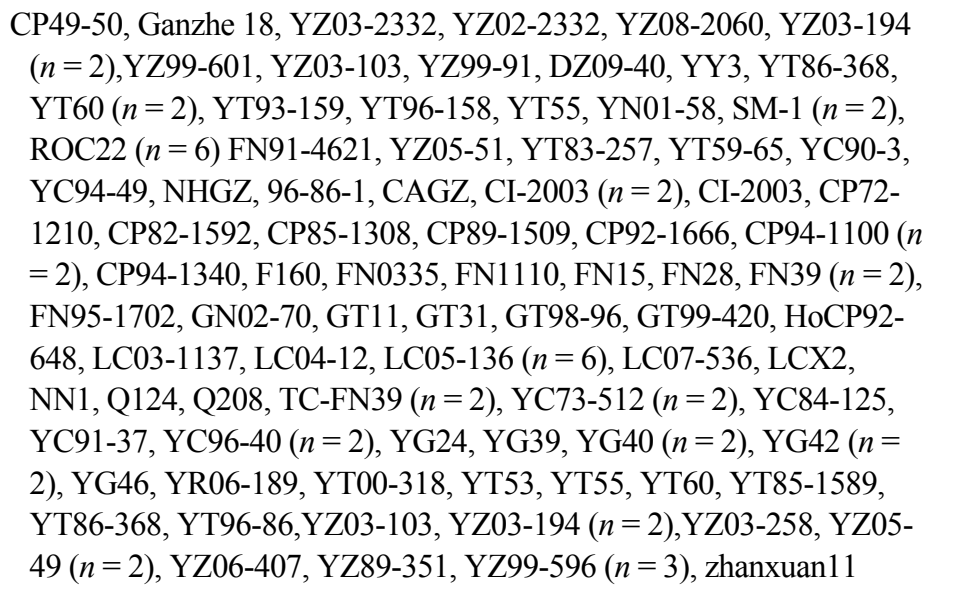 & Lin et al. $\left(2014^{a}\right)$ \\
\hline & & & $\begin{array}{l}\text { YT96-86, YT86-368, YC84-125, FN02-3924, YZ82-54, YZ59-58, } \\
\text { YT93-159, YT86-368, YC98-2, MT96-649, GT96-287, GT93-102, } \\
\text { FN95-1702, FN96-0907 }\end{array}$ & Gao et al. (2012) \\
\hline & & 2 & FN96-0907 $(n=2)$ & Gao et al. $\left(2005^{\mathrm{a}}\right)$ \\
\hline & & 3 & Sugarcane ( $n=3)$ (Saccharum hybrid) & $\begin{array}{l}\text { Rassaby et al. }\left(2003^{\mathrm{a}}\right), \text { Zhang et } \\
\text { al. (2011), Zhou et al. }\left(2006^{\mathrm{a}}\right)\end{array}$ \\
\hline & & 1 & FN96-0907 & Wang et al. $\left(2009^{\mathrm{a}}\right)$ \\
\hline & & 2 & CP93-1309, Funong28 & Wang et al. $\left(2010^{a}\right)$ \\
\hline & & 28 & $\begin{array}{l}\text { Badila }(n=2) \text {, CHN-GD-ZJ4, CP93-1634 }(n=3) \text {, Funong28, Gui11, Mint- } \\
\text { ang 69-421, ROC10 }(n=2), \text { ROC22 }(n=5), \text { ROC25, Taitang27-67 }(n=2) \text {, } \\
\text { Yuetang00-236, Yunrui85-601 }(n=2) \text {, Yunrui99-601 }(n=2) \text {, Yunyin18 } n \\
=3) \text {, Zhe } 0403\end{array}$ & Wang et al. $\left(2010^{\mathrm{a}}\right)$ \\
\hline & & 25 & Sugarcane $(n=25)$ (Saccharum hybrid) & Wang et al. $\left(2010^{\mathrm{a}}, 2014^{\mathrm{a}}, 2017^{\mathrm{a}}\right)$ \\
\hline & & 2 & Ganzhe 18, CP49-50 & Lin et al. $\left(2013^{\mathrm{a}}\right)$ \\
\hline
\end{tabular}


Table 1. Continued

\begin{tabular}{|c|c|c|c|c|}
\hline $\begin{array}{l}\text { Sl. } \\
\text { No. }\end{array}$ & Country & $\begin{array}{l}\text { No. of } \\
\text { SCYLV } \\
\text { isolates }\end{array}$ & Variety/Host & Reference \\
\hline \multirow[t]{2}{*}{6} & China & 1 & ROC22 & Zhang et al. $\left(2010^{a}\right)$ \\
\hline & & 1 & CGT63-167 & Ahmad et al. (2006a, 2006b) \\
\hline 7 & Guatemala & 1 & CP92-1654 (clone) & Moonan and Mirkov (2002) \\
\hline \multirow[t]{5}{*}{8} & India & 3 & cv. 'Bharani' (2003 V 46) $(n=2)$ & Hemalatha et al. $\left(2012^{\mathrm{a}}\right)$ \\
\hline & & 20 & $\begin{array}{l}\text { B } 38192(n=2), \text { Co 419, Co 85019, Co 86010, Co 86032 }(n=2), \text { CoBln } \\
\text { 9605, CoC 671, CoC 85061, CoPant 84211, CoSi 6, CoTl 85441, CoV } \\
\text { 09356, CoV 92102, CP 961252, D1135, MOL 4503, SP 811763, CoLk } \\
97154\end{array}$ & Chinnaraja et al. (2013) \\
\hline & & 11 & $\begin{array}{l}\text { Melanaphis indosacchari CoC 671, CoJn 862035, CoLk 97154, CoV } \\
92102(n=2), \text { Co } 86032(n=3), \text { Co } 86010, \text { CoC } 85061\end{array}$ & $\begin{array}{l}\text { Viswanathan et al. }\left(2007^{\mathrm{a}} \text {, }\right. \\
\left.2008^{\mathrm{a}}\right)\end{array}$ \\
\hline & & 29 & $\begin{array}{l}\text { 93A53, B38192 }(n=2) \text {, Co 6304, Co 85019, Co 86010, Co } 86032(n=3) \text {, } \\
\text { Co 91010, Co 94005, Co 94006, Co 94008, Co 99016, CoC } 671(n=2) \text {, } \\
\text { CoJn 862035, CoLk 97154, CoV 94101 }(n=2) \text {, Black Tanna, C } 81129 \text {, } \\
\text { Co 86010, Co 86032, CoS 611, CoS 767, D1135, Madhurima, Q63 }\end{array}$ & $\begin{array}{l}\text { Viswanathan et al. }\left(2007^{\mathrm{a}} \text {, }\right. \\
\left.2008^{\mathrm{a}}\right)\end{array}$ \\
\hline & & 14 & $\begin{array}{l}\text { CoJ 83, CoLK 5203, CoLK 97147, CoSe 05451, Sugarcane, } 87 \text { R40, Co } \\
\text { 62399, Co 7219, Co 7717, Co 86010, Co 93009, CoC } 671(n=2), \text { CoJ } 64\end{array}$ & Gaur et al. $\left(2003^{\mathrm{a}}\right)$ \\
\hline 9 & Jamaica & 1 & Sugarcane (Saccharum hybrid) & Chinnaraja et al. (2013) \\
\hline 10 & Kenya & 4 & Sugarcane $(n=4)$ (Saccharum hybrid) & Fernandez et al. $\left(2015^{\mathrm{a}}\right)$ \\
\hline 11 & Malaysia & 2 & Sugarcane $(n=2)$ (Saccharum hybrid) & Rassaby et al. $\left(2003^{\mathrm{a}}\right)$ \\
\hline \multirow[t]{4}{*}{12} & Mauritius & 3 & CO6304, PR67245, S17 & Joomun et al. $\left(2010^{a}\right)$ \\
\hline & & 6 & R_570 $(n=3)$, R_579 $(n=2)$, M $\_2024 / 88$ & Joomun et al. $\left(2017^{\mathrm{a}}\right)$ \\
\hline & & 8 & $\mathrm{M} 2350-79(n=3), \mathrm{M} 1658-78(n=5)$ & Borg et al. $\left(2002^{\mathrm{a}}\right)$ \\
\hline & & 4 & Sugarcane $(n=4)$ (Saccharum hybrid) & $\begin{array}{l}\text { Chomic et al. }(2010) \text {, } \\
\text { Rassaby et al. }\left(2003^{\mathrm{a}}\right)\end{array}$ \\
\hline 13 & Martinique & 1 & FR91485 & Ahmad et al. (2006a, 2006b) \\
\hline 14 & Mexico & 2 & Sugarcane $(n=2)$ (Saccharum hybrid) & Bermudez et al. $\left(2015^{\mathrm{a}}\right)$ \\
\hline 15 & $\begin{array}{l}\text { Papua New } \\
\text { Guinea }\end{array}$ & 1 & Saccharum hybrid cultivar 57NG56 & Chinnaraja et al. (2013) \\
\hline \multirow[t]{2}{*}{16} & Peru & 4 & H50-7209, H32-8560 & Ahmad et al. (2006a, 2006b) \\
\hline & & & Sugarcane $(n=2)$ (Saccharum hybrid) & Rassaby et al. $\left(2003^{\mathrm{a}}\right)$ \\
\hline \multirow[t]{2}{*}{17} & Philippines & 1 & Sugarcane (Saccharum hybrid) & Rassaby et al. $\left(2003^{a}\right)$ \\
\hline & & 1 & VMC76-16 & Ahmad et al. (2006a, 2006b) \\
\hline \multirow[t]{5}{*}{18} & Reunion & 34 & $\begin{array}{l}\text { AY7 }(n=2), \mathrm{CP} 85-1491, \mathrm{H} 50-7209, \mathrm{R} 490(n=4), \mathrm{R} 570(n=4), \\
\text { R575 }(n=6), \mathrm{R} 576, \mathrm{R} 577, \mathrm{R} 579(n=5), \mathrm{R} 81-0834(n=2), \\
\text { R83-1592, S17, SP71-6163 }(n=5)\end{array}$ & Ahmad et al. (2006a, 2006b) \\
\hline & & 33 & Sugarcane $(n=33)$ (Saccharum hybrid) & Rassaby et al. $\left(2003^{\mathrm{a}}\right)$ \\
\hline & & 2 & Sugarcane $(n=2)$ (Saccharum hybrid) & Lin et al. $\left(2016^{\mathrm{a}}\right)$ \\
\hline & & 13 & $\begin{array}{l}\text { AY7, R569, R570 }(n=4), \operatorname{R} 575(n=2), \operatorname{R} 577, \operatorname{R} 579(n=2) \\
\quad \operatorname{SP} 71-6163(n=2)\end{array}$ & Rassaby et al. $\left(2003^{\mathrm{a}}\right)$ \\
\hline & & 10 & $\begin{array}{l}\text { CP81-1405 }(n=2), \operatorname{CP} 88-1409(n=2), \operatorname{R} 84-0408(n=3), \\
\quad \operatorname{R} 85-1102(n=3)\end{array}$ & Borg et al. $\left(2002^{\mathrm{a}}\right)$ \\
\hline 19 & Senegal & 1 & Sugarcane (Saccharum hybrid) & Rassaby et al. $\left(2003^{\mathrm{a}}\right)$ \\
\hline 20 & $\begin{array}{l}\text { South } \\
\text { Africa }\end{array}$ & 5 & $\mathrm{~N} 30(n=4)$, Saccharum officinarum & $\begin{array}{l}\text { Borg et al. }\left(2002^{\mathrm{a}}\right) \\
\text { Chomic et al. }(2010)\end{array}$ \\
\hline 21 & Sri Lanka & 1 & SLC9225 & Ahmad et al. (2006a, 2006b) \\
\hline 22 & Taiwan & 9 & ROC6, ROC11 $(n=4), \operatorname{ROC} 12(n=4)$ & $\begin{array}{l}\text { Ahmad et al. }(2006 \mathrm{a}, 2006 \mathrm{~b}), \\
\text { Borg et al. }\left(2002^{\mathrm{a}}\right)\end{array}$ \\
\hline
\end{tabular}


Table 1. Continued

\begin{tabular}{|c|c|c|c|c|}
\hline $\begin{array}{l}\text { Sl. } \\
\text { No. }\end{array}$ & Country & $\begin{array}{l}\text { No. of } \\
\text { SCYLV } \\
\text { isolates }\end{array}$ & Variety/Host & Reference \\
\hline 23 & Tunisia & 3 & Sugarcane $(\mathrm{n}=3)$ (Saccharum hybrid) & Bouallegue et al. (2014) \\
\hline \multirow[t]{11}{*}{24} & USA & 1 & CP85-1491 & Rassaby et al. $\left(2003^{\mathrm{a}}\right)$ \\
\hline & & 8 & $\begin{array}{l}\mathrm{H} 73-6110(n=3), \mathrm{H} 87-4319, \mathrm{H} 87-4094(n=3), \mathrm{CP} 52-43 \\
\text { Saccharum hybrid cultivar H87-4094 }(n=2)\end{array}$ & ElSayed et al. (2011) \\
\hline & & 1 & TCP87-3388 & Ahmad et al. (2006a, 2006b) \\
\hline & & 3 & CP65-357, CP88-1409, LHo83-153 (Clone) & Moonan et al. (2000) \\
\hline & & 1 & CР65-357 & Moonan et al. $\left(1999^{\mathrm{a}}\right)$ \\
\hline & & 2 & Sugarcane (Saccharum hybrid), CP65-357 & Smith et al. (2000) \\
\hline & & 3 & CP00-1101, CL91-4814, IJ76-478 & Filloux et al. (2018) \\
\hline & & 22 & $\begin{array}{l}\text { CP65-357 }(n=8), \text { CP81-1405 }(n=2), \text { CP88-1409 }(n=3), \\
\text { H78-3606 }(n=4), \text { H78-7750, H87-4094 }(n=4)\end{array}$ & Borg et al. $\left(2002^{\mathrm{a}}\right)$ \\
\hline & & 1 & Sugarcane (Saccharum hybrid) & Rassaby et al. $\left(2003^{\mathrm{a}}\right)$ \\
\hline & & 1 & Melanaphis sacchari & ElSayed et al. (2011) \\
\hline & & 3 & $\begin{array}{l}\text { Sorghum bicolor cv. Top76-6, Sorghum bicolor cv. Dale, Sorghum bi- } \\
\text { color cv. Keller }\end{array}$ & ElSayed et al. (2015) \\
\hline
\end{tabular}

SCYLV, Sugarcane yellow leaf virus; ORF, open reading frame.

${ }^{a}$ Unpublished sequence information retrieved from NCBI GenBank based on accession numbers., and not included in list of references.

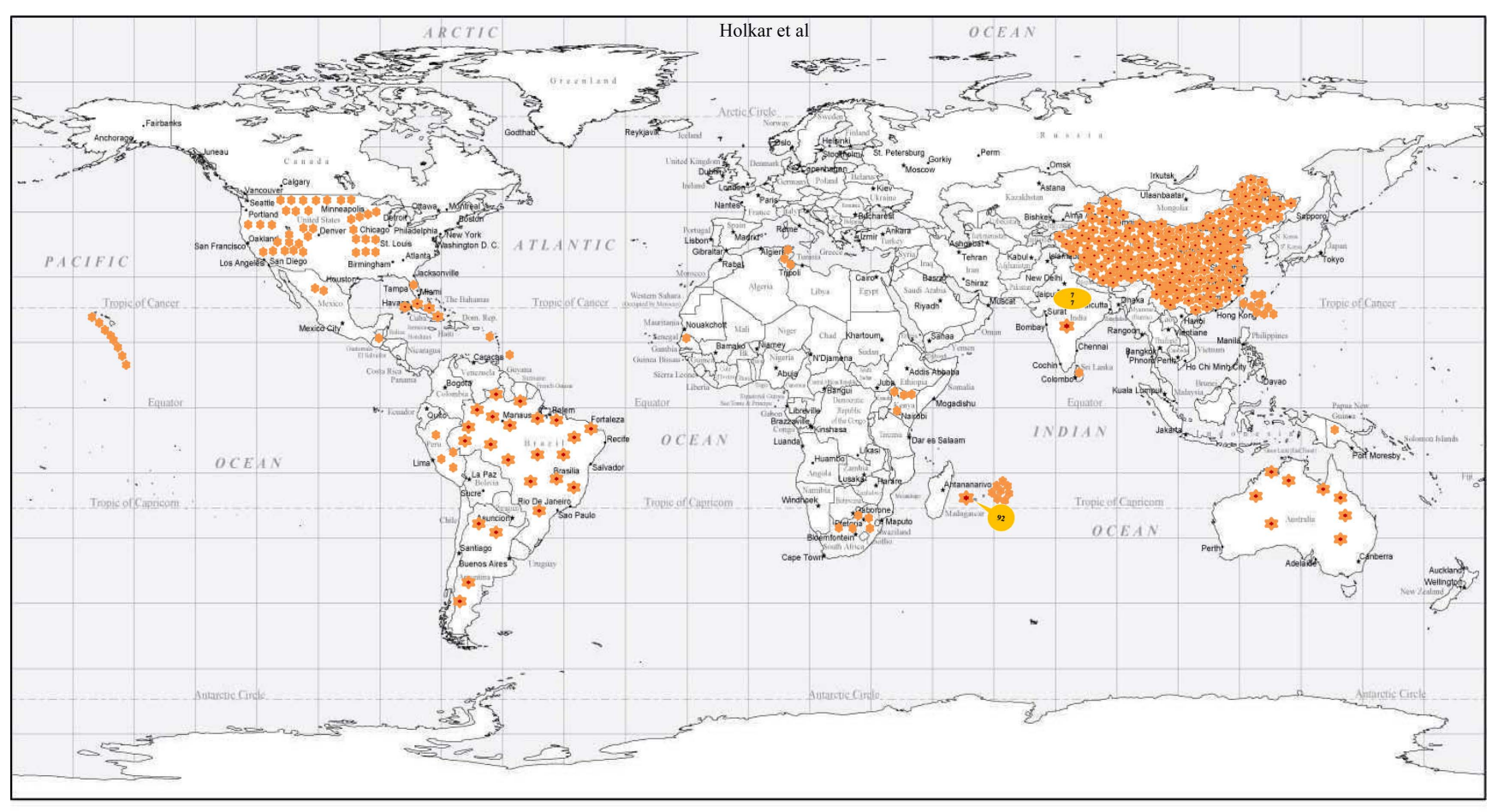

$\underbrace{1000 \mathrm{~km}}$

Fig. 3. Spread of Sugarcane yellow leaf disease based on geographical distribution of Sugarcane yellow leaf curl virus (SCYLV) in sugarcane. Data presented based on sequence information of SCYLV retrieved from NCBI GenBank https://www.ncbi.nlm.nih.gov/.

$77 \%$ to $80 \%$ homology based on amino acids sequence in ORF1 with virus isolates originating from these three genotypes. Therefore, the Cuban isolate was designated as
CUB, a separate genotype (Ahmad et al., 2006b). Based on the phylogenetic relationships, genotypes PER and BRA showed close relationships. Later, both the PER and BRA 
were pooled and designated them as BRA-PER genotype (Ahmad et al., 2006b).

Subsequently, Viswanathan et al. (2008) characterized four SCYLV isolates from India. These four isolates (SCYLV-IND) showed amino acids sequence differences with those from REU, PER, and BRA in partial ORF0 sequence and therefore the Indian genotype was designated as IND. Phylogenetic analysis showed a separate lineage for IND isolates. Based on sequence information of ORF1 and ORF2, Indian isolates showed that the YLD sugarcane in India is known to be caused by either of the three genotypes, viz., CUB, IND and BRA-PER. Most of the isolates were found infected by CUB genotype followed by IND and BRA-PER genotypes. Subsequently, whole genome of four SCYLV isolates were characterized from India and showed the separate lineage for Indian isolates based on

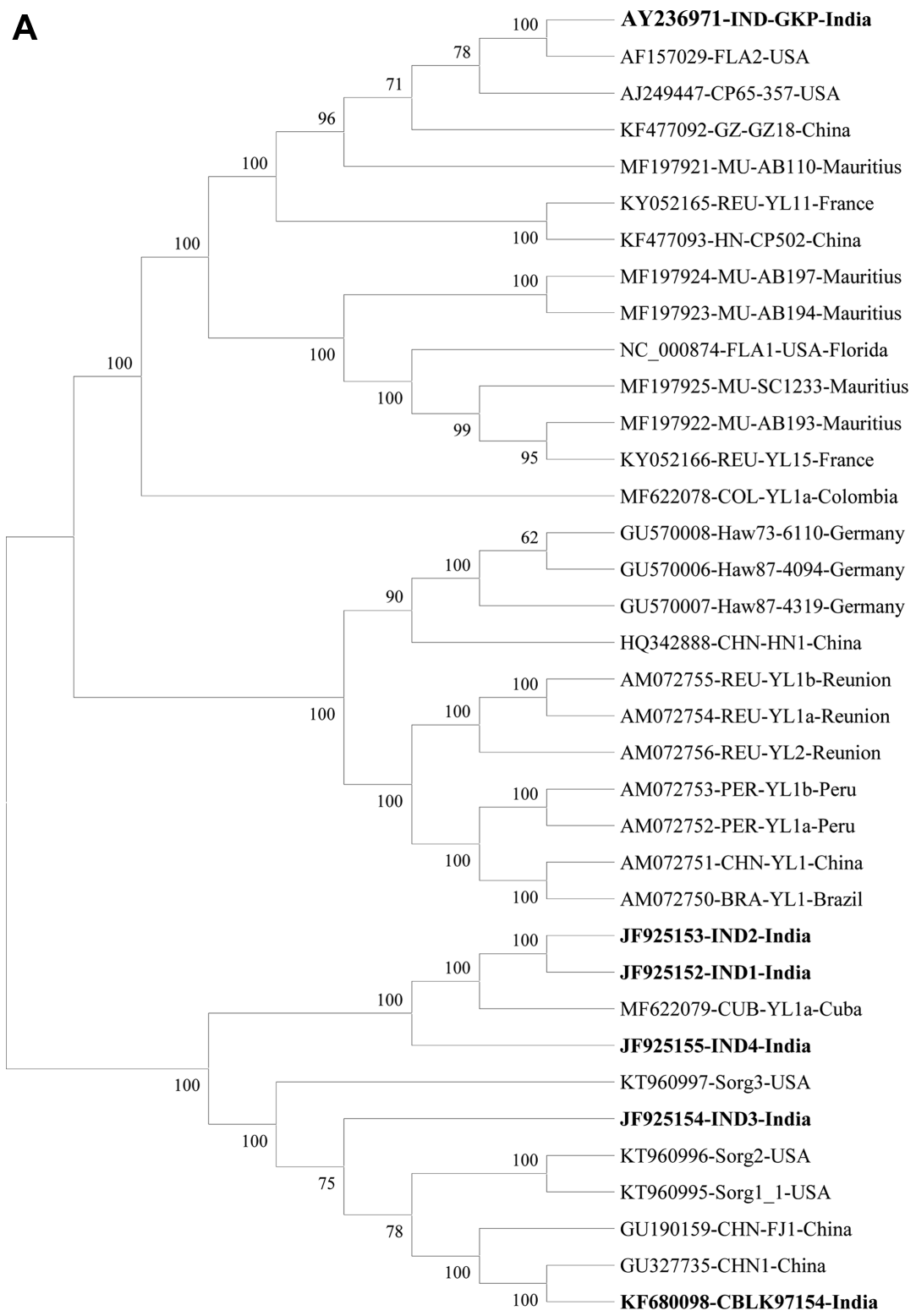

Fig. 4. Evolutionary analyses of Sugarcane yellow leaf virus (SCYLV) genotypes originating from different countries from sugarcane (10 genotypes) and sorghum (three isolates) (A) were conducted in MEGA6 (Tamura et al., 2013). The evolutionary history was inferred using the neighbor-joining method (Saitou and Nei, 1987). The optimal tree with the sum of branch length $=1.89755463$. The percentage of replicate trees in which the associated taxa clustered together in the bootstrap test $(1,000)$ are shown next to the branches (Felsenstein, 1985). The evolutionary distances were computed using the Poisson correction method (Zuckerkandl and Pauling, 1965). Total 36 virus isolates with 6,700 positions in the dataset. (Continued) 

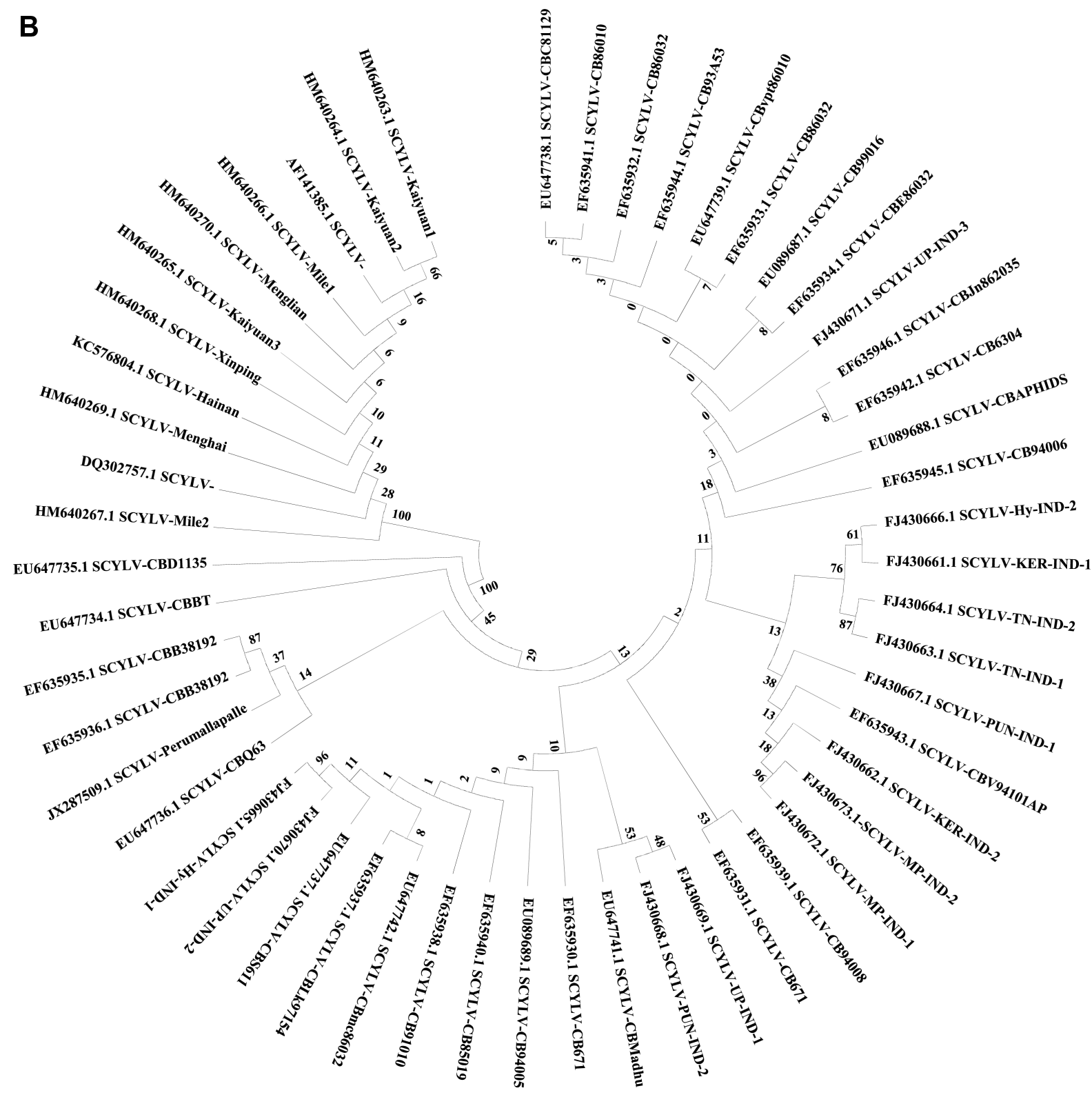

Fig. 4. Continued. (B) Evolutionary analyses of the 53 SCYLV isolates originating from different countries from sugarcane based on coat protein were conducted in MEGA6 (Tamura et al., 2013). The evolutionary history was inferred using the neighbor-joining method (Saitou and Nei, 1987). The optimal tree with the sum of branch length $=0.15509519$. The percentage of replicate trees in which the associated taxa clustered together in the bootstrap test $(1,000)$ are shown next to the branches (Felsenstein, 1985). The evolutionary distances were computed using the Poisson correction method (Zuckerkandl and Pauling, 1965) with 591 positions in the dataset. MU, Mauritius; REU, Reunion; HN, Hainan-China; GZ, Guizhou-China; CP, Un-named-USA; IND-GKP, Gorakhpur-India; IND1-4, Coimbatore-India; FLA1-2, Florida-USA; CUB, Cuba; COL, Colombia; CHN-FJ1, Fujian-China; CHN-HN1, Hainan-China; CBLK, Lucknow-India; PER, Peru; BRA, Brazil; HAW, Hawaii-USA; Sorg1-3, Sorghum-USA.

the phylogenetic analyses of the partial ORF0, ORF1 and ORF5 (Chinnaraja et al., 2013).

Genome sequence of 36 virus isolates and its aa level comparisons showed that the IND isolates shared $86.5 \%$ to $86.7 \%$ sequence identity with the virus isolates belong- ing to CHN1 genotype. Whereas, $88.6 \%$ to $90.4 \%$ identity with the Cuba isolates (CUB) and $88.1 \%$ to $90.1 \%$ with the $\mathrm{COL}$ isolates. Whereas, the least sequence identity was obtained with the isolates originating from REU, BRA, and HAW which showed $69.0 \%$ to $73.5 \%, 69.0 \%$ to $70.1 \%$ 
and $70.7 \%$ to $71.9 \%$, respectively. Moreover, IND1, IND2, IND3, and IND4 shared closest sequence homology with the other Indian isolates which ranged from $92.3 \%$ to 93.5\% (Supplementary Table 1). Phylogenetic analyses of the 36 virus isolates based on the complete genome information, six Indian isolates showed close relationship and clustering with the CHN, CUB, COL, and FLA (Florida) isolates. The IND3 isolate showed a separate cluster with distinct isolates as compared to other Indian isolates (Fig. 4A). Three virus isolates from sorghum showed separate clustering with the isolates belonging to HAW genotype (Fig. 4A). At present, CP sequence information of 53 virus isolates is available in GenBank, all Indian isolates showed $97 \%-100 \%$ aa sequence identity (data not shown). The phylogenetic analyses of these 53 isolates showed three separate clades of India and China isolates (Fig. 4B).

\section{Mechanism of Plant-Virus Interaction}

Plant viruses are obligate organisms and depend upon the host cell protein synthesizing components for their persistence and replication. SCYLV is an aphid borne viral pathogen. Once the virus particles are inoculated by insects in the sugarcane plants, virus proliferates, replicates and moves from one cell to another through plasmodesmata and from one part to another and produce the symptoms on foliage. SCYLV encodes six various proteins, and their interactions ensure transmission by insects and persistence in plant. Presently, least information available on specific site of host-virus protein interaction though such evidences are essential for devising virus management strategies. Some of the host and Polerovirus (PLRV) proteins interactions were studied (Baumberger et al., 2007; Pazhouhandeh et al., 2006; Reinbold et al., 2013; Rodriguez-Medina et al., 2015), however, they do not provide any evidence on direct interactions. Recently, direct protein-protein interactions studies were conducted by application of the protein interactions reporter, a novel technology and demonstrated how PLRV utilize host proteins throughout plant infection (DeBlasio et al., 2016). Further, such studies are required for SCYLV and host interactions and prior to that the efficient SCYLV infectious clone development needs to be worked out.

\section{Recombination, Mutation, and Evolution of SCYLV}

Genetic diversity analysis showed that SCYLV evolved through RNA-recombination between the species of three genera i.e., Luteovirus, Polerovirus and Enamovirus (D'Arey and Domier, 2005; Aaziz and Tepfer, 1999;
Moonan et al., 2000; Smith et al., 2000). Previous studies on recombination in SCYLV genome (Chinnaraja et al., 2013; ElSayed et al., 2014, 2018; Lin et al., 2014) revealed that recombination is a dominant feature for evolution of SCYLV and is much similar to that of other RNA viruses (Ohshima et al., 2007). Moreover, recombinations among the 36 SCYLV complete genomes were detected using seven different programs executed in recombination (Martin et al., 2015). Selection pressure analysis was carried out based on SCYLV complete genomes using maximum likelihood model in the phylogenetic analysis (Yang, 2007). Four different procedures executed in Datamonkey Adaptive Evolution Server (http://www.datamonkey.org) were also utilized to calculate (dN: Non synonymous) and (dS: Synonymous) ratio of every codon. Recombination hot spots reported throughout the 17 complete genomes of SCYLV and revealed that it is a prominent attribute for evolution, similar observations were also recorded from different countries (Supplementary Table 2) (Chinnaraja et al., 2013; ElSayed et al., 2014, 2018; Lin et al., 2014).

Analysis of selection pressure among 36 virus isolates stated that to a very great degree different codons of complete genomes were under neutral or negative selection except for three codons $(255,249$, and 225). The quantitative relationship between (dN: Non synonymous) and (dS: Synonymous) per codon site was calculated by PAML 4.0, which gave value of 0.162, suggesting neutral or negative selection. Further, each individual nucleotide was tested statistically using SLAC (Single-Likelihood Ancestor Counting), REL (Random Effects Likelihood), FEL (Fixed Effects Likelihood), and MEME (Mixed Effects Model of Evolution) methods available from Adaptive Evolution Server and were showed to be negative $(P$ $<0.05$ ), suggesting a very robust purifying selection (data not shown) (Kondrashov, 1988). Based on the mutational deterministic hypothesis (Kondrashov, 1988), mutation is largely deleterious, creating mutational loads and causing existence of isolates that have many slightly deleterious mutations. Twenty-eight recombination events discovered in this study can be explained by this hypothesis; recombination hot spots along with very strong purifying selection may enhance the speed of complete removal of deleterious mutations in the SCYLV genes as described earlier in case of helper component proteinase genes of SCSMV (Bagyalakshmi et al., 2012). The maximum recombination of major and minor parents contributed in the Indian SCYLV isolates (Supplementary Table 2) in the genetic recombination with different SCYLV genotypes suggests an ancestral Indian origin of SCYLV. 


\section{Mechanism of Virus-Vector Interaction}

SCYLV was believed to be transmitted by three species of aphids viz., Melanaphis sacchari (Zehntner), generally known as sugarcane aphid, Rhopalosiphum maidis (Fitch) known as corn leaf aphid and $R$. rufiabdominalis known as rice root aphid in Hawaii (Edon-Jock et al., 2007; Schenck and Lehrer, 2000). Later, it was confirmed that only $M$. sacchari transmits the virus in Hawaii. Initial spread of the virus occurs through infected seed cane (Viswanathan et al., 2006, 2008). Numerous investigations have revealed the secondary transmission capability and effectiveness that $M$. sacchari is the prominent vector to SCYLV (Ahmad et al., 2007; Lehrer et al., 2007; Rassaby et al., 2004; Scagliusi and Lockhart, 2000). The virus resides in phloem parenchymatous tissues of plants and spread by insect-vectors (aphids) in a persistent, circulative, and nonpropagative means and cannot be transmitted by artificial sap inoculation (Rochow, 1982). Incidence of M. sacchari and its transmissibility was reported from different locations including Mauritius (Behary Paray et al., 2011), Guadeloupe (Francki et al., 1985), and Louisiana (McAllister et al., 2008). In China, natural occurrence and transmission of SCYLV by Ceratovacuna lanigera was studied (Zhou et al., 2006). Among these, M. sacchari is prominent vector transmitting SCYLV in sugarcane worldwide (Rott et al., 2008). Transmissibility of SCYLV is preserved for the complete life of aphids and not even lost during their molting.

Chinnaraja and Viswanathan (2015) studied the virus transmission by inoculating micro-propagated virus-free plantlets of sugarcane cv. Co 86032 with M. sacchari, which harbours SCYLV. Further, virus transmission was confirmed through RT-PCR and RT-qPCR assays. Natural occurrence of sugarcane aphid colony was observed on sugarcane cv. Co 419 in the experimental plot at Indian Institute of Sugarcane Research (IISR), Lucknow, India (Fig. 1A).

To transmit and identify the new hosts under greenhouse conditions numerous investigations were demonstrated on SCYLV transmission by aphids in different crop plants viz., barley (Hordeum vulgare L.), oats (Avena sativa L.), corn (Zea mays L.), wheat (Triticum aestivum L), and rice (Oryza sativa L.). Results revealed that $90 \%$ SCYLV transmission was obtained in the inoculated seedlings of wheat, oats and barley, while $10 \%$ virus transmission was obtained in the inoculated rice and corn plants by M. sacchari (Schenck and Lehrer, 2000). Moreover, natural transmission on

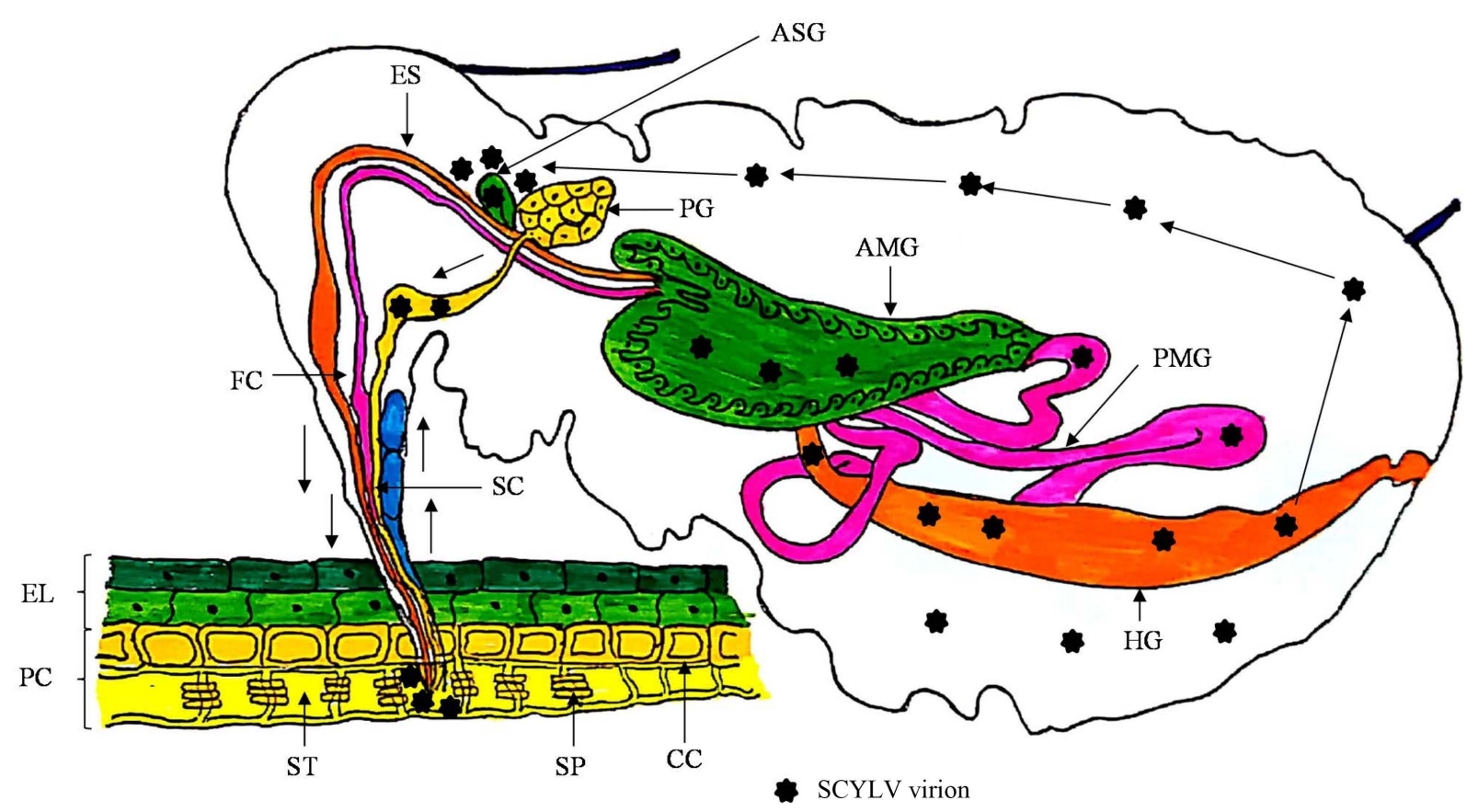

Fig. 5. Mechanism of Sugarcane yellow leaf virus (SCYLV) transmission by aphids in a persistent circulative, and non-propagative manner with piercing and sucking type of mouth parts. The general anatomy of the aphids is shown with the alimentary canal, salivary system and host cells with the following labels. AMG, anterior midgut; ASG, accessory salivary glands; CC, companion cells; EL, epidermal layer of the host; ES, esophagus; FC, food canal; HG, hindgut; PC, parenchyma cells; PG, principal salivary glands; PMG, posterior midgut; SC, salivary canal; SP, sieve plate; ST, sieve tube cell. 
these hosts does not occurs when nearby SCYLV infected sugarcane fields are available (Komor, 2011). Recently, three inherently dissimilar haplotypes of $M$. sacchhari were reported from United States including haplotype one (H1) infecting Sorghum species and sugarcane whereas, H3 haplotype known to occur on sugarcane, sorghum and Johnsongrass ( $S$. halepense) and H6 haplotype colonizes both sugarcane and Johnsongrass (Nibouche et al., 2018). Moreover, from Florida, lack of efficient transmission of SCYLV from sugarcane and Columbus grass to sugarcane has been shown by M. sacchari and mites (Oligonychus grypus), suggesting the SCYLV vector needs further identification (Boukari et al., 2020).

Polerovirus members transmit the virus by circulative, persistent and non-propagative manner, therefore do not replicate in insect-vectors but circulates into the insect gut, hemolymph and salivary glands for further transmission (Bragard et al., 2013; Pinheiro et al., 2015). Members of this genus are phloem-limited, therefore insect-vectors need extensive feeding for effective transmission from one plant to another (Gray et al., 2014). Members belonging to the family Luteoviridae follow the transcytotic dissemination pathway (Gutiérrez et al., 2013). After the entry of virions in the aphid mouthparts, are moved through foregut, midgut and hindgut. Initially, virion interactions occur with the epithelial cells of gut having receptors which facilitates the adherence on midgut and or hindgut via endocytosis. Afterwards, with the help of exocytosis phenomenon virus particles travel to the haemocoel, which passes through, subsequently, virions reach to salivary glands for its transmissibility via saliva while probing for the plant sap (Garret et al., 1996; Gildow, 1993; Gray et al., 2014). Transmission and acquisition of the members of family Luteoviridae is very specific and mediated by major and minor $\mathrm{CP}$ and RTP (Gray et al., 2014; Peter et al., 2008). CP is essential for the translocation of virions from gut to haemocoel whereas, RTP is prerequisite for interaction and movement by the membranes of salivary glands (Bruyère et al., 1997). A schematic representation of the phenomenon of virus-vector interaction of SCYLV is presented (Fig. 5). Moreover, it has anticipated that the role of endosymbionts in the haemocoel cannot be avoided for virion acquisition and transmission processes, still this needs further studies to pin-point their direct or indirect functions.

\section{Strategies for Management of SCYLV}

Managing SCYLV is difficult due to its vector-borne nature and transmission through infected seed cane. Disease severity varies from different varieties cultivated in differ- ent agro-climatic conditions worldwide. Nevertheless, integrated management strategies including cultural, chemical, biological, and other conventional strategies including identification of sources of resistance and breeding for disease resistance and non-conventional approaches including pathogen derived resistance, RNA silencing, miRNA and CRISPR/Cas (Clustered Regularly Interspaced Palindromic Repeats) needs to be adopted.

\section{Conventional Management Strategies}

Healthy seed cane production by three-tier system must be emphasized for enhanced sugarcane productivity in India (Singh and Singh, 2015). Wide-row spacing and early planting can alleviate the impact of YLD (Palaniswami et al., 2014; Viswanathan et al., 2017a). Multiple vegetative propagation of single seed should not be practiced. Moreover, varietal purity needs to be maintained to avoid any admixture of other YLD susceptible varieties. Disease surveillance through remote sensing technique has been recommended for the monitoring and identification of YLD affected sugarcane fields (Palaniswami et al., 2014; Viswanathan et al., 2017a). Yellow sticky traps can also be found effective against management of sugarcane aphids (Satyagopal et al., 2014).

Biological control of aphid vectors could possibly reduce the widespread occurrence and spread of YLD in sugarcane. It has been demonstrated that $45 \%$ reduction in aphids was achieved due to the practise of application of grey fungus Verticillium lecanii (Hall, 1987). Moreover, some predators have been showed very efficient bio-control agent for $M$. sacchari infesting sugarcane includingOlla v-nigrum (Mulsant), Allograpta exotica (Wiedemann), Coleomegilla maculate fuscilabris (Mulsant), Hippodamia convergens (Guerin), Diomus terminates (Say), Lysiphle bustestaceipes (Cresson), Micromus subanticus (Walker), Chrysoperla externa (Hagan), and Cycloneda sanguinea (L.) (Hall, 1987, 1988; White et al., 2001). Application of $0.05 \%$ solution of dimethoate $30 \mathrm{EC}$ was found to be effective against $M$. sacchari with the reduction up to $83.3 \%$ of sugarcane aphid population. Whereas, application of endosulfan $35 \mathrm{EC}$ at $0.07 \%$, monocrotophos $36 \mathrm{WSC}$ at $0.04 \%$ or chlorpyriphos $20 \mathrm{EC}$ at $0.05 \%$ can efficiently control aphid population up to $80.2 \%, 79.7 \%$, and $77.5 \%$, respectively (Balikai, 2004; Viswanathan et al., 2017a). However, application of insecticide sprays to manage aphids is not feasible when crop in field is more than five to six months old, for which automatic aerial sprays are helpful.

In order to develop virus resistant genotypes, identification of source of resistance is the prerequisite, therefore, 
Lehrer and Komor (2008), developed 0-6 disease rating scale for evaluation of sugarcane genotypes against YLD under field conditions. Later, Chinnaraja and Viswanathan (2015) developed a rating scale $0-5$ based on varying disease symptoms under field studies to find out the sources of resistance against YLD. Subsequently, Viswanathan et al. (2016) screened large number of genotypes (more than $4,000)$ and recognized 463 SCYLV resilient genotypes from different clones while 773 from the Saccharum spp. Recently, Kumar et al. (2020) screened 189 sugarcane genotypes from tropical and sub-tropical regions of India using a similar 0-5 rating scale. Among the screened genotypes, 95 genotypes showed moderately susceptible to susceptible to YLD while, 94 genotypes showed resistant against YLD. Thus, these findings laid foundation for the improvement of YLD resistant sugarcane progenies in India.

Apical meristem tip culture, auxiliary bud culture and leaf roll callus culture techniques have been found effective in the management of YLD in commercial and noble sugarcane cultivars (Chatenet et al., 2001; Fitch et al., 2001; Parmessur et al., 2002). Meristem tip culture and auxiliary bud culture are the most advantageous and common methods for virus elimination from all susceptible varieties, due to an advantage of the fact that, meristematic tissue remains free from virus (Fitch et al., 2001; Parmessur et al., 2002). Fitch et al. (2001) described that plantlets developed from meristematic tips, where the $1-2 \mathrm{~mm}$ explants formed healthy plants and that remained SCYLV free for four years, despite the fact that they were grown in isolated fields or in the glasshouse condition. Meristem tip culture technique using $0.3 \mathrm{~mm}$ meristem tip are useful to develop $64 \%$ of the disease-free plantlets (Fitch et al., 2001). Leaf rolls callus culture is also most efficient technique which can be used for elimination of virus. Callus resultant from early growing leaf-rolls found $100 \%$ removal of SCYLV without any abnormal growth in any of the plantlets (Chatenet et al., 2001; Guiderdoni and Demarly, 1988; Parmessur et al., 2002).

Viswanathan et al. (2018) has efficiently validated impact of virus-free planting materials of sugarcane variety, Co 86032 through meristem tip culture technique. Thus, use of improved diagnostic techniques and production of virus-free plants through meristem tip culture have been found as a feasible strategy to manage YLD and it facilitates continuous supply of healthy seedlings to the sugarcane growers for enhanced and sustained sugarcane productivity in India. Production of disease-free sugarcane seedlings is the prerequisite for enhanced production and productivity. Therefore, tissue culture through meristem tip culture technique provides a best platform for the raising of virus-free and genetically uniform plantlets.

Currently, nested PCR and RT-PCR techniques have been routinely followed for of phytoplasma detection and virus-indexing, respectively infecting sugarcane. Tissue culture producing commercial ventures in India are routinely being followed the virus-indexing and genetic fidelity services from accredited test laboratories (ATLs) established under the national certification system for tissue culture-raised plants system of Department of Biotechnology, Govt. of India, in collaboration with Biotech Consortium India Limited (BCIL), New Delhi for the production and distribution of virus-free and true-to-type seedlings to the growers in India. For its successful implementation DBT has identified two referral centres and five ATLs which certify the tissue culture produced plants based on results of virus indexing and genetic fidelity testing in sugarcane and other crops. One of such ATL's at ICAR-IISR, Lucknow and ICAR-Sugarcane Breeding Institute (SBI), Coimbatore displayed a key role in the qualification of tissue culture-raised sugarcane plantlets which were produced by different production units (Holkar et al., 2016b; Kumar et al., 2017; Viswanathan et al., 2017a).

\section{Next Generation Strategies for Management of SCYLV}

Vegetative propagation of sugarcane favours accumulation of SCYLV and becomes difficult to manage by conventional approaches. Further, no genes have been identified within the Saccharum gene pool that confers resistance to SCYLV. To develop virus-resistant transgenic plants, RNA and protein mediated resistance have been the fundamental rule. These approaches have originated from the impression of pathogen derived resistance (PDR) (Sanford and Johnston, 1985). In case of PDR, RNA or pathogen-coded proteins are utilized for preventing important stages in the infection phase of the pathogen. Transgenic resistance based on RNA interference (RNAi) has already proved in sugarcane based on truncated CP gene of SrMV (Ingelbrecht et al., 1999) and SCYLV (Zhu et al., 2011).

Insufficient SCYLV resistance sources limit the conventional resistance breeding program. Gilbert et al. (2009) conducted a field study in Belle Glade, Florida for the evaluation of level of SCYLV resistance in transgenic lines viz., 6-1, 6-2 and also for their agronomic performance in comparison with the parent genotype CP 92-1,666 (SCYLV susceptible). Further, characterized the genetic changes in the 6-1 and 6-2 lines in comparison with the parental cultivar using simple sequence repeat (SSR) genotyping. Therefore, the study was considered to be the first suc- 
cessful gene transfer for SCYLV resistance in sugarcane and also first to report variation in microsatellite markers amalgamated with regeneration from embryogenic callus. An RNAi expression vector harbouring CP gene fragment of SCYLV was constructed based on the complete genome sequence of SCYLV Hainan isolate (GenBank accession no. HQ342888). The RNAi vector p2300-CP-F-R containing a hairpin structure was confirmed and transformed into 12 tobacco lines by Agrobacterium-mediated transformation system. The CP gene was integrated into the genome of tobacco (Zhang et al., 2011). This work constructed the base for breeding of plant mediated RNAi technology in sugarcane against disease.

Similarly, efforts have been made on the use of nucleotide binding sites-resistance gene analogue (NBS-RGA) markers and kinase analogues from soybean and wheat to amplify DNA from sugarcane. Sugarcane cultivar US011158 was recognized as resistant against SCYLV and moderately resistant against rust pathogen (Puccinia melanocephala) (Glynn et al., 2008). Moreover, certain studies have explored the genetic variability of resistance against SCYLV in sugarcane germplasm, Saccharum spontaneum and S. barberi, and other genera viz., Miscanthus spp. and Erianthus spp. showed the least disease incidence (Comstock et al., 2001; Komor, 2011).

The tolerant and resistant phenotypes are generally governed by several genes and are expressed as quantitative trait loci (QTLs). QTL mapping studies in Saccharum hybrids identified is more difficult than other crops due to the complex genome of sugarcane because of its ploidy level, large size genome and interspecific origin. Therefore, it is a challenge for genetic studies. First such major quantitative major allele was tagged for resistance against SCYLV known as Ryll relied on QTL by bi-parental progeny of a resistant clone and a susceptible cultivar (Costet et al., 2012). Izquierdo et al. (2013) generated genetic map of sugarcane to detect molecular markers linked with resistance to SCYLV. Total 148 progenies were obtained from the cross between CC 84-75× RD 75-11, SCYLV susceptible and resistant respectively, and were used for mapping. A genome wide association study was also carried out to detect resistant markers (polymorphic diversity arrays technology [DArT] and amplified fragment length polymorphism [AFLP]) in sugarcane against SCYLV in different sugarcane germplasm (Debibakas et al., 2014; Yang et al., 2019). A total of 1465 polymorphic bands were revealed using microsatellite, AFLP and DArT markers. The identification of SCYLV was assessed using tissue-blot and RTPCR. The integrated genetic map of the two cultivars had
122 linkage groups and coverage of $8.560 \mathrm{cM}$. The genetic linkage analyses allowed the confirmation of a putative resistant gene to the SCYLV at $16.3 \mathrm{cM}$ of one AFLP marker (Debibakas et al., 2014). Further, SCYLV resistance studies were demonstrated using routine molecular markers including DArT, SSR, restriction fragment length polymorphism, and AFLP (Costet et al., 2012; Debibakas et al., 2014). For the characterization genetic base of resistance against SCYLV in sugarcane, Yang et al. (2017) constructed a genetic map having high-density consisting of 4,607 markers based on genotyping by sequencing of a segregating F1 progeny (parents: CP95-1039 and CP881762) and this population also evaluated for SCYLV reaction. Similarly, genomic maps were generated using GBS based markers for CP95-1039 and CP88-1762 by following a pseudo-testcross method. In this study, two QTLs were identified for resistance against SCYLV, among them QTL qSCYLR79 associated with marker 3PAV3154 showed to be specific for SCYLV resistance (Islam et al., 2018). Recently, You et al. (2019) developed an Axiom Sugarcane $100 \mathrm{~K}$ single nucleotide polymorphism display and magnificently employed to develop the genetic map of sugarcane and to recognize the QTL linked with SCYLV resistance. This arrangement was used to genotype 469 sugarcane clones, having one F1 (parents: Green German and IND81-146), one selfing populations obtained from CP80-1827 and 11 different sugarcane stocks as controls. The genotyping revealed 18 QTLs controlling SCYLV resistance segregating in the two mapping populations, harbouring 27 genes for disease resistance.

\section{Conclusions and Perspectives}

An unusual occurrence of SCYLV on sugarcane during 1960s in the form of "yellow wilt" in Tanzania was followed by its further reemergence and widespread distribution in Hawaii, Brazil and subsequently in 25 sugarcane cultivating countries due to its primary and secondary transmission by seed cane and aphid vectors, respectively. Due to severe occurrence of YLD on many sugarcane varieties led up to $50 \%$ crop loss in Brazil followed by $37 \%$ in Reunion Island, $30 \%$ in Thailand and $15 \%$ in United States. In India, many sugarcane genotypes have been found degenerated due to its widespread occurrence. SCYLV has been mainly infecting sugarcane, grain sorghum and Columbus grass. Worldwide, during the last twenty years notable research has been performed on diagnosis using recent molecular techniques, genome characterization, genetic diversity, and management by producing healthy 
seed cane through meristem tip culture and three-tier seed production programme. To address the severe loss in yield due to SCYLV, disease rating scales 0-6 and 0-5 are available and therefore, identification of the sources of resistant genotypes from tropical and sub-tropical condition have been worked out. The systematic studies on virus-vector transmission, presence of virus in asymptomatic plants have been achieved. IDM approaches for management of the disease need to follow to reduce the crop loss.

In the recent years, our understanding of SCYLV has enhanced substantially, nevertheless many queries remain unaddressed on plant-virus interactions, epidemiology, identification of resistant genes and management using CRISPR/ Cas technology. The rapid and widespread global occurrence of SCYLV underlines the importance for developing more effective management measures, with considering the possible changes in the virus genome by recombination and evolution. Much efforts are required in identification of resistant genes by mining different genotypes and their subsequent use in developing total resistance against SCYLV. Early detection of the virus in seed cane or in the nursery seedling is the first phase towards devising effective virus management steps, and the virus transmissibility through seed cane in the plated crop is very difficult and more challenging. Virus spread by aphid vectors is manageable at the early stages of the crop, after six months age of the crop the practical application of insecticide becomes more difficult. Therefore, to address this issue, certain aerial drone-based sprayers must be developed and which would be having advantage of managing other insect-pests and diseases of significance in sugarcane. Nevertheless, systematic studies are required to ascertain the existence of other possible aphid species naturally transmitting SCYLV in sugarcane, sorghum and other members belonging to Poaceae family needs to be explored. Genetic engineering has been proved effective against the virus management but due to policy issues it is limited to the research field. Further, development of virus-vectors and virus management using novel techniques like CRISPR/Cas mediated resistance necessarily to be addressed in near future.

\section{Conflicts of Interest}

No potential conflict of interest relevant to this article was reported.

\section{Acknowledgments}

Authors are thankful to Dr. A. D. Pathak, Director, ICARIISR Lucknow and Dr. B. Ram, Director, ICAR-SBI, Co- imbatore for their constant support and encouragement for writing this review article. No any financial support was received.

\section{Electronic Supplementary Material}

Supplementary materials are available at The Plant Pathology Journal website (http://www.ppjonline.org/).

\section{References}

Aaziz, R. and Tepfer, M. 1999. Recombination in RNA viruses and in virus-resistant transgenic plants. J. Gen. Virol. 80:1339-1346.

Ahmad, Y. A., Costet, L., Daugrois, J.-H., Nibouche, S., Letourmy, P., Girard, J.-C. and Rott, P. 2007. Variation in infection capacity and in virulence exists between genotypes of Sugarcane yellow leaf virus. Plant Dis. 91:253-259.

Ahmad, Y. A., Rassaby, L., Royer, M., Borg, Z., Braithwaite, K. S., Mirkov. T. E., Irey, M. S., Perrier, X., Smith, G. R. and Rott, P. 2006a. Yellow leaf of sugarcane is caused by at least three different genotypes of Sugarcane yellow leaf virus, one of which predominates on the Island of Reunion. Arch. Virol. 151:1355-1371.

Ahmad, Y. A., Royer, M. and Daugrois, J.-H. 2006b. Geographical distribution of four Sugarcane yellow leaf virus genotypes. Plant Dis. 90:1156-1560.

Aljanabi, S. M., Parmessur, Y., Moutia, Y., Saumtally, S. and Dookun, A. 2001. Further evidence of the association of a phytoplasma and a virus with yellow leaf syndrome in sugarcane. Plant Pathol. 50:628-636.

Amata, R. L, Fernandez, E., Filloux, D., Martin, D. P., Rott, P. and Roumagnac, P. 2016. Prevalence of Sugarcane yellow leaf virus in sugarcane-producing regions in Kenya revealed by reverse-transcription loop-mediated isothermal amplification method. Plant Dis. 100:260-268.

Anandakumar, L., Bagyalakshmi, K., Nithya, K., Parameswari, B. and Viswanathan, R. 2018. Reverse transcription loop-mediated isothermal amplification (RT-LAMP) assay for rapid diagnosis of Sugarcane yellow leaf virus in sugarcane. Sugar Tech 20:708-716.

Arocha, Y., Gonzalez, L., Peralta, E. L. and Jones, P. 1999. First report of virus and phytoplasma pathogens associated with yellow leaf syndrome of sugarcane in Cuba. Plant Dis. 83:1177.

Bagyalakshmi, K., Parameswari, B., Chinnaraja, C., Karuppaiah, R., Kumar, V. G. and Viswanathan, R. 2012. Genetic variability and potential recombination events in the HC-Pro gene of sugarcane streak mosaic virus. Arch. Virol. 157:1371-1375.

Bailey, R. A., Bechet, G. R. and Cronje, C. P. R. 1996. Notes on the occurrence of yellow leaf syndrome of sugarcane in southern Africa. Proc. S. Afr. Sugar Technol. Assoc. 70:3-6.

Balikai, R. A. 2004. Chemical control of sugarcane leaf aphid, 
Melanaphis sacchari (Zehntner) on rabi sorghum. Agric. Sci. Digest 24:142-144.

Baumberger, N., Tsai, C.-H., Lie, M., Havecker, E. and Baulcombe, D. C. 2007. The polerovirus silencing suppressor P0 targets ARGONAUTE proteins for degradation. Curr. Biol. 17:1609-1614.

Behary Paray, N., Khoodoo, M. H. R., Saumtally, A. S. and Ganeshan, S. 2011. Vector-virus relationship for Melanaphis sacchari (Zehnt.) (Hemiptera: Aphididae) transmitting Sugarcane yellow leaf Luteovirus in Mauritius. Sugar Tech 13:7780.

Bertani, P. R., Perera, M. F., Arias, M. E., Luque, C., Funes, C., González, V., Cuenya, M. I., Ploper, L. D., Welin, B. and Castagnaro, A. P. 2014. A study of the sugarcane yellow leaf disease in Argentina. Plant Dis. 98:1036-1042.

Birchfield, W. 1984. Nematode parasites of sugarcane. In: Plant and insect nematodes, ed. by W. R. Nickel, pp. 571-589. Marcel Dekker, New York, NY, USA.

Borth, W., Hu, J. S. and Schenck, S. 1994. Double-stranded RNA associated with sugarcane yellow leaf syndrome. Sugar Cane 3:5-8.

Bouallegue, M., Mezghani-Khemakhem, M., Makni, H. and Makni, M. 2014. First report of Sugarcane yellow leaf virus infecting barley in Tunisia. Plant Dis. 98:1016.

Boukari, W., Kaye, C., Wei, C., Hincapie, M., LaBorde, C., Irey, M. and Rott, P. 2019. Field infection of virus-free sugarcane by Sugarcane yellow leaf virus and effect of yellow leaf on sugarcane grown on organic and on mineral soils in Florida. Plant Dis. 103:2367-2373.

Boukari, W., Wei, C., Tang, L., Hincapie, M., Naranjo, M., Nuessly, G., Beuzelin, J., Sood, S. and Rott, P. 2020. Lack of transmission of Sugarcane yellow leaf virus in Florida from Columbus grass and sugarcane to sugarcane with aphids or mites. PLoS ONE 15:e0230066.

Bragard, C., Caciagli, P., Lemaire, O., Lopez-Moya, J. J., MacFarlane, S., Peters, D., Susi, P. and Torrance, L. 2013. Status and prospects of plant virus control through interference with vector transmission. Annu. Rev. Phytopathol. 51:177-201.

Braithwaite, K. S., Egeskov, N. M. and Smith, G. R. 1995. Detection of Sugarcane bacilliform virus using the polymerase chain reaction. Plant Dis. 79:792-796.

Bruyère, A., Brault, V., Ziegler-Graff, V., Simonis, M. T., Van den Heuvel, J. F. J. M., Richards, K., Guilley, H., Jonard, G. and Herrbach, E. 1997. Effects of mutations in the Beet western yellows virus readthrough protein on its expression and packaging and on virus accumulation, symptoms, and aphid transmission. Virology 230:323-334.

Chatenet, M., Delage, C., Ripolles, M., Irey, M., Lockhart, B. E. L. and Rott, P. 2001. Detection of Sugarcane yellow leaf virus in quarantine and production of virus-free sugarcane by apical meristem culture. Plant Dis. 85:1177-1180.

Chinnaraja, C. and Viswanathan, R. 2015. Variability in yellow leaf symptom expression caused by the Sugarcane yellow leaf virus and its seasonal influence in sugarcane. Phytoparasitica
43:339-353.

Chinnaraja, C. and Viswanathan, R. 2017. Sugarcane yellow leaf virus and its impact in sugarcane. Lambert Academic Publishing (LAP), Balti, Republic of Moldova. 288 pp.

Chinnaraja, C., Viswanathan, R., Karuppaiah, R., Bagyalakshmi, K., Malathi, P. and Parameswari, B. 2013. Complete genome characterization of Sugarcane yellow leaf virus from India: evidence for RNA recombination. Eur. J. Plant Pathol. 135:335-349.

Chinnaraja, C., Viswanathan, R., Sathyabhama, M., Parameswari, B., Bagyalakshmi, K., Malathi, P. and Neelamathi, D. 2014. Quantification of Sugarcane yellow leaf virus in in vitro plantlets and asymptomatic plants of sugarcane by RT-qPCR. Curr. Sci. 106:729-734.

Chomic, A., Pearson, M. N., Clover, G. R. G., Farreyrol, K., Saul, D., Hampton, J. G. and Armstrong, K. F. 2010. A generic RTPCR assay for the detection of Luteoviridae. Plant Pathol. 59:429-442.

Comstock, J. C., Irey, M. S., Lockhart, B. E. L. and Wang, Z. K. 1998. Incidence of yellow leaf syndrome in CP cultivars based on polymerase chain reaction and serological techniques. Sugar Cane 4:21-24.

Comstock, J. C., Irvine, J. E. and Miller, J. D. 1994. Yellow leaf syndrome appears on the United States mainland. Sugar J. 56:33-35.

Comstock, J. C. and Miller, J. D. 2003. Incidence and spread of Sugarcane yellow leaf virus in sugarcane clones in the CP cultivar development program at canal point. J. Am. Soc. Sugarcane Technol. 23:71-78.

Comstock, J. C. and Miller, J. D. 2004. Yield comparisons: disease-free tissue culture versus bud-propagated sugarcane plants and healthy versus yellow leaf infected plants. J. Am. Soc. Sugar Cane Technol. 24:31-40.

Comstock, J. C., Miller, J. D. and Schnell, R. J. 2001. Incidence of Sugarcane yellow leaf virus in clones maintained in the world collection of sugarcane and related grasses at the United States National Repository in Miami, Florida. Sugar Tech 3:128-133.

Comstock, J. C., Miller, J. D., Tai, P. Y. P. and Follis, J. E. 1999. Incidence of and resistance to Sugarcane yellow leaf virus in Florida. Proc. Int. Soc. Sugar Cane Technol. 23:366-372.

Costet, L., Raboin, L.-M., Payet, M., D'Hont, A. and Nibouche, S. 2012. A major quantitative trait allele for resistance to the Sugarcane yellow leaf virus (Luteoviridae). Plant Breed. 131:637-640.

Cronje, C. P. R., Tymon, A. M., Jones, P. and Bailey, R. A. 1998. Association of a phytoplasma with a yellow leaf syndrome of sugarcane in Africa. Ann. Appl. Biol. 133:177-186.

D'Arey, C. J. D. and Domier, L. L. 2005. Luteoviridae. In: Virus Taxonomy: 8th Report of the International Committee on Taxonomy of Viruses, eds. by C. M. Fauquet, M. A. Mayo, J. Maniloff, U. Desselberger and L. A. Ball, pp. 891-900. Academic Press, New York, NY, USA.

Debibakas, S., Rocher, S., Garsmeur, O., Toubi, L., Roques, D., 
D’Hont, A., Hoarau, J.-Y. and Daugrois, J. H. 2014. Prospecting sugarcane resistance to Sugarcane yellow leaf virus by genome-wide association. Theor. Appl. Genet. 127:17191732.

DeBlasio, S. L., Chavez, J. D., Alexander, M. M., Ramsey, J., Eng, J. K., Mahoney, J., Gray, S. M., Bruce, J. E. and Cilia, M. 2016. Visualization of host-polerovirus interaction topologies using protein interaction reporter technology. J. Virol. 90:1973-1987.

Dinesh-Kumar, S. P. and Miller, W. A. 1993. Control of start codon choice on a plant viral RNA encoding overlapping genes. Plant Cell 5:679-692.

Edon-Jock, C., Rott, P., Vaillant, J., Fernandez, E., Girard, J.-C. and Daugrois, J.-H. 2007. Status of Sugarcane yellow leaf virus in commercial fields and risk assessment in Guadeloupe. Proc. Int. Soc. Sugar Cane Technol. 26:995-1004.

Elsayed, A. I., Boulila, M., Odero, D. C. and Komor, E. 2018. Phylogenetic and recombination analysis of sorghum isolates of Sugarcane yellow leaf virus. Plant Pathol. 67:221-232.

ElSayed, A. I., Boulila, M. and Rott, P. 2014. Molecular evolutionary history of Sugarcane yellow leaf virus based on sequence analysis of RNA-dependent RNA polymerase and putative aphid transmission factor-coding genes. J. Mol. Evol. 78:349-365.

ElSayed, A. I., Komor, E., Boulila, M., Viswanathan, R. and Odero, D. C. 2015. Biology and management of Sugarcane yellow leaf virus: an historical overview. Arch. Virol. 160:29212934.

ElSayed, A. I., Weig, A. R. and Komor, E. 2011. Molecular characterization of Hawaiian Sugarcane yellow virus leaf genotypes and their phylogenetic relationship to strains from other sugarcane-growing countries. Eur. J. Plant Pathol. 129:399412.

Espinoza-Delgado, H. V., Kaye, C., Hincapie, M., Boukari, W., Wei, C., Fernandez, J. V., Mollov, D., Comstock, J. C. and Rott, P. 2016. First report of Sugarcane yellow leaf virus infecting Columbus grass (Sorghum almum) in Florida. Plant Dis. 100:1027.

Felsenstein, J. 1985. Confidence limits on phylogenies: an approach using the bootstrap. Evolution 39:783-91.

Filloux, D., Fernandez, E., Comstock, J. C., Mollov, D., Roumagnac, P. and Rott, P. 2018. Viral metagenomic-based screening of sugarcane from Florida reveals occurrence of six sugarcane-infecting viruses and high prevalence of Sugarcane yellow leaf virus. Plant Dis. 102:2317-2323.

Fitch, M. M. M., Lehrer, A. T., Komor, E. and Moore, P. H. 2001. Elimination of Sugarcane yellow leaf virus from infected sugarcane plants by meristem tip culture visualized by tissue blot immunoassay. Plant Pathol. 50:676-680.

Flynn, J., Powell, G., Perdomo, R., Monres, G., Quebedeaux, K. and Comstock, J. C. 2005. Comparison of sugarcane disease incidence and yield of field-run, heat-treated, and tissue culture based seed cane. J. Am. Soc. Sugar Cane Technol. 25:88100 .
Francki, R. I. B., Milne, R. G. and Hatta, T. 1985. Atlas of plant viruses, Vol. 1. CRC Press, Boca Raton, FL, USA. 238 pp.

Gao, S.-J., Lin, Y.-H., Pan, Y.-B., Damaj, M. B., Wang, Q.-N., Mirkov, T. E. and Chen, R.-K. 2012. Molecular characterization and phylogenetic analysis of Sugarcane yellow leaf virus isolates from China. Virus Genes 45:340-349.

Garret, A., Kerlan, C. and Thomas, D. 1996. Ultrastructural study of acquisition and retention of Potato leafroll luteovirus in the alimentary canal of its aphid vector, Myzus persicae Sulz. Arch. Virol. 141:1279-1292.

Giedroc, D. P. and Cornish, P. V. 2009. Frameshifting RNA pseudoknots: structure and mechanism. Virus Res. 139:193-208.

Gilbert, R. A., Glynn, N. C., Comstock, J. C. and Davis, M. J. 2009. Agronomic performance and genetic characterization of sugarcane transformed for resistance to Sugarcane yellow leaf virus. Field Crops Res. 111:39-46.

Gildow, F. E. 1993. Evidence for receptor-mediated endocytosis regulating luteovirus acquisition by aphids. Phytopathology 83:270-277.

Glynn, N. C., Comstock, J. C., Sood, S. G., Dang, P. M. and Chaparro, J. X. 2008. Isolation of nucleotide binding siteleucine rich repeat and kinase resistance gene analogues from sugarcane (Saccharum spp.). Pest Manag. Sci. 64:48-56.

Gonçalves, M. C., Klerks, M. M., Verbeek, M., Vega, J. and van den Heuvel, J. F. J. M. 2002. The use of molecular beacons combined with NASBA for the sensitive detection of Sugarcane yellow leaf virus. Eur. J. Plant Pathol. 108:401-407.

Gonçalves, M. C., Pinto, L. R., Souza, S. C. and Landell, M. G. A. 2012. Virus diseases of sugarcane: a constant challenge to sugarcane breeding in Brazil. Funct. Plant Sci. Biotechnol. 6:108-116.

Gonçalves, M. C., Vega, J., Oliveira, J. G. and Gomes, M. M. A. 2005. Sugarcane yellow leaf virus infection leads to alterations in photosynthetic efficiency and carbohydrate accumulation in sugarcane leaves. Fitopatol. Bras. 30:10-16.

Gray, S., Cilia, M. and Ghanim, M. 2014. Circulative, "nonpropagative" virus transmission: an orchestra of virus-, insect-, and plant-derived instruments. Adv. Virus Res. 89:141-199.

Grisham, M. P., Eggleston, G., Hoy, J. W. and Viator, R. P. 2009. The effect of Sugarcane yellow leaf virus infection on yield of sugarcane in Louisiana. Sugar Cane Int. 27:91-94.

Grisham, M. P., Pan, Y. B., Legendre, B. L., Godshall, M. A. and Eggleston, G. 2001. Effect of Sugarcane yellow leaf virus on sugarcane yield and juice quality. Proc. Int. Soc. Sugar Cane Technol. 24:434-438.

Guiderdoni, E. and Demarly, Y. 1988. Histology of somatic embryogenesis in cultured leaf segments of sugarcane plantlets. Plant Cell Tissue Org. Cult. 14:71-88.

Gutiérrez, S., Michalakis, Y., Van Munster, M. and Blanc, S. 2013. Plant feeding by insect vectors can affect life cycle, population genetics and evolution of plant viruses. Funct. Ecol. 27:610-622.

Hall, D. G. 1987. The sugarcane aphid, Melanaphis sacchari (Zehntner), in Florida. J. Am. Soc. Sugar Cane Technol. 7:26- 
29.

Hall, D. G. 1988. Insects and mites associated with sugarcane in Florida. Fla. Entomol. 71:138-150.

Hodgetts, J., Tomlinson, J., Boonham, N., González-Martín, I., Nikolić, P., Swarbrick, P., Yankey, E. N. and Dickinson, M. 2011. Development of rapid in-field loop-mediated isothermal amplification (LAMP) assays for phytoplasmas. Bull. Insectol. 64(Suppl):S41-S42.

Holkar, S. K., Gupta, H., Kumar, A., Baitha, A., Kumar, S. and Singh, J. 2016a. Diagnosis of yellow leaf disease of sugarcane from subtropical India. In: National Symposium on Ecofriendly Approaches for Plant Disease Management: Recent Trends and Opportunities, p. 177. ICAR-Indian Institute of Pulses Research, Kanpur, India.

Holkar, S. K., Kumar, A., Singh, N., Khan, M. S., Singh, R. K. and Kumar, S. 2016b. Testing and certification of tissue culture-raised quality planting material at accredited test laboratory, ICAR-IISR, Lucknow. In: National Conference on Challenges, Opportunities and Innovative Approaches in Sugarcane: Agriculture, Bio-energy and Climate Change, p. 177. Uttar Pradesh Council of Sugarcane Research, Shahajahanpur, India.

Holkar, S. K., Lal, R., Kumar, S., Pandey, D. K., Singh, P. K. and Kumar, A. 2015. Occurrence of yellow leaf disease (YLD) on sugarcane genotypes for North-West region of subtropical India. In: National Symposium-cum Mid-eastern Zone Meeting of IPS on Impact of Climate Change on Plant-microbe Interactions and Its Implications, pp. 57-58. Banaras Hindu University, Varanasi, India.

Hull, R. 2002. Matthews plant virology. 4th ed. Elsevier Academic Press, San Diego, CA, USA. 1056 pp.

Ingelbrecht, I. L., Irvine, J. E. and Mirkov, T. E. 1999. Posttranscriptional gene silencing in transgenic sugarcane: dissection of homology-dependent virus resistance in a monocot that has a complex polyploid genome. Plant Physiol. 119:1187-1198.

Irey, M. S., Baucum, L. E., Derrick, K. S., Manjunath, K. L. and Lockhart, B. E. 1997. Detection of the luteovirus associated with yellow leaf syndrome of sugarcane (YLS) by a reverse transcriptase polymerase chain reaction and incidence of YLS in commercial varieties in Florida. In: 5th ISSCT Pathology and 2nd ISSCT Molecular Biology Combined Workshop. Umhlanga Rocks, South Africa.

Islam, M. S., Yang, X., Sood, S., Comstock, J. C. and Wang, J. 2018. Molecular characterization of genetic basis of Sugarcane yellow leaf virus (SCYLV) resistance in Saccharum spp. hybrid. Plant Breed. 137:598-604.

Izaguirre-Mayoral, M. L., Carballo, O., Alceste, C., Romano, M. and Nass, H. A. 2002. Physiological performance of asymptomatic and yellow leaf syndrome-affected sugarcanes in Venezuela. J. Phytopathol. 150:13-19.

Izquierdo, P., Gutierrez, A., Victoria, J. I., Angel, J. C., Avellaneda, M. C. and Lopez, J. 2013. Molecular markers associated with resistance to Sugarcane yellow leaf virus. In: Proceedings of the XXVIIIth Congress, pp. 1179-1188. International
Society of Sugar Cane Technologists, Sao Paulo, Brazil.

King, A. M., Lefkowitz, E., Adams, M. J. and Carstens, E. B. 2011. Virus taxonomy: ninth report of the International Committee on Taxonomy of Viruses. Vol. 9. Elsevier, San Diego, CA, USA. 1327 pp.

Komor, E. 2011. Susceptibility of sugarcane, plantation weeds and grain cereals to infection by Sugarcane yellow leaf virus and selection by sugarcane breeding in Hawaii. Eur. J. Plant Pathol. 129:379-388.

Kondrashov, A. S. 1988. Deleterious mutations and the evolution of sexual reproduction. Nature 336:435-440.

Korimbocus, J., Coates, D., Barker, I. and Boonham, N. 2002. Improved detection of Sugarcane yellow leaf virus using a real-time fluorescent (TaqMan) RT-PCR assay. J. Virol. Methods 103:109-120.

Kumar, S., Holkar, S. K. and Khan, M. S. 2017. Micropropagation technique for development of disease-free and genetically uniform seed cane. Indian Farm. 67:37-40.

Kumar, A., Holkar, S. K. and Singh, R. 2020. Screening of sugarcane genotypes against yellow leaf disease in tropical and sub-tropical conditions in India. In: 7th International Conference on Phytopathology in Cchieving UN Sustainable Development Goals, p. 307. ICAR-Indian Agricultural Research Institute, New Delhi, India.

Lefkowitz, E. J., Dempsey, D. M., Hendrickson, R. C., Orton, R. J., Siddell, S. G. and Smith, D. B. 2018. Virus taxonomy: the database of the International Committee on Taxonomy of Viruses (ICTV). Nucleic Acids Res. 46:D708-D717.

Lehrer, A. T. and Komor, E. 2008. Symptom expression of yellow leaf disease in sugarcane cultivars with different degrees of infection by Sugarcane yellow leaf virus. Plant Pathol. 57:178-189.

Lehrer, A. T. Kusalwong, A. and Komor, E. 2008. High incidence of Sugarcane yellow leaf virus (SCYLV) in sugar plantations and germplasm collections in Thailand. Aust. Plant Dis. Notes 3:89-92.

Lehrer, A. T., Schenck, S., Yan, S.-L. and Komor, E. 2007. Movement of aphid-transmitted Sugarcane yellow leaf virus (ScYLV) within and between sugarcane plants. Plant Pathol. 56:711-717.

Lehrer, A. T., Wu, K. K. and Komor, E. 2009. Impact of Sugarcane yellow leaf virus on growth and sugar yield of sugarcane. J. Gen. Plant Pathol. 75:288-296.

Lin, Y.-H., Gao, S.-J., Damaj, M. B., Fu, H.-Y., Chen, R.-K. and Mirkov, T. E. 2014. Genome characterization of Sugarcane yellow leaf virus from China reveals a novel recombinant genotype. Arch. Virol. 159:1421-1429.

Lockhart, B. E. L. and Cronje, C. P. R. 2000. Yellow leaf syndrome. In: A guide to sugarcane diseases, eds. by P. Rott, R. A. Bailey, J. C. Comstock, B. J. Croft and A. S. Saumtally, pp. 291-295. CIRAD-ISSCT, Montpellier, France.

Lockhart, B. E. L., Irey, M. J. and Comstock, J. C. 1996. Sugarcane bacilliform virus, Sugarcane mild mosaic virus and Sugarcane yellow leaf syndrome. In: Sugarcane germplasm con- 
servation and exchange, eds. by B. J. Croft, C. M. Piggin, E. S. Wallis, and D. M. Hogarth, pp. 108-112. Australian Centre for International Agricultural Research, Canberra, Australia.

Madugula, S. and Gali, U. D. 2017. Virus indexing for Sugarcane yellow leaf virus (SCYLV) in field varieties and in vitro regenerated plantlets of sugarcane. Aust. Plant Pathol. 46:433439.

Madugula, S. and Gali, U. D. 2018. Detection of Sugarcane yellow leaf virus (SCYLV) causing yellow leaf disease (YLD) of sugarcane using serological and molecular tools. Int. Clin. Pathol. J. 6:58-62.

Madugula, S., Gali, U., Nalabolu, R. K. and Merugu, T. 2020. Current status of yellow leaf disease (YLD) of sugarcane caused by Sugarcane yellow leaf virus (ScYLV) in the states of Andhra Pradesh and Telangana. Int. J. Bio-resour. Stress Manag. 11:73-81.

Maia, I. G., Gonçalaves, M. C., Arruda, P. and Vega, J. 2000. Molecular evidence that Sugarcane yellow leaf virus (ScYLV) is a member of the Luteoviridae family. Arch. Virol. 145:10091019.

Mangwende, T., Ming, L.-W., Borth, W., Hu, J., Moore, P. H., Mirkov, T. E. and Albert, H. H. 2009. The P0 gene of Sugarcane yellow leaf virus encodes an RNA silencing suppressor with unique activities. Virology 384:38-50.

Martin, D. P., Murrell, B., Golden, M., Khoosal, A. and Muhire, B. 2015. RDP4: detection and analysis of recombination patterns in virus genomes. Virus Evol. 1:vev003.

Mayo, M. A. and Miller, W. A. 1999. The structure and expression of Luteovirus genomes. In: The Luteoviridae, eds. by $\mathrm{H}$. G. Smith and H. Barker, pp. 23-42. CABI Publishing, Wallingford, UK.

McAllister, C. D., Hoy, J. W. and Reagan, T. E. 2008. Temporal increase and spatial distribution of the sugarcane yellow leaf and infestations of the aphid vector, Melanaphis sacchari. Plant Dis. 92:607-615.

Moonan, F. and Mirkov, T. E. 2002. Analyses of genotypic diversity among North, South, and Central American isolates of Sugarcane yellow leaf virus: evidence for Colombian origins and for intraspecific spatial phylogenetic variation. J. Virol. 76:1339-1348.

Moonan, F., Molina, J. and Mirkov, T. E. 2000. Sugarcane yellow leaf virus: an emerging virus that has evolved by recombination between luteoviral and poleroviral ancestors. Virology 269:156-171.

Moutia, J. F. Y. and Saumtally, S. 1999. Symptomology of yellow leaf syndrome and detection and distribution of Sugarcane yellow leaf virus in Mauritius. Proc. Int. Soc. Sugar Cane Technol. 23:355-364.

Nair, S., Manimekalai, R., Raj, P. G. and Hegde, V. 2016. Loop mediated isothermal amplification (LAMP) assay for detection of coconut root wilt disease and arecanut yellow leaf disease phytoplasma. World J. Microbiol. Biotechnol. 32:108.

Nibouche, S., Costet, L., Holt, J. R., Jacobson, A., Pekarcik, A., Sadeyen, J., Armstrong, J. S., Peterson, G. C., McLaren, N. and Medina, R. F. 2018. Invasion of sorghum in the Americas by a new sugarcane aphid (Melanaphis sacchari) superclone. PLoS ONE 13:e0196124.

Ohshima, K., Tomitaka, Y., Wood, J. T., Minematsu, Y., Kajiyama, H., Tomimura, K. and Gibbs, A. J. 2007. Pattern of recombination in Turnip mosaic virus genomic sequences indicates hotspots of recombination. J. Gen. Virol. 88:298-315.

Palaniswami, C., Viswanathan, R., Bhaskaran, A., Rakkiyappan, P. and Gopalasundaram, P. 2014. Mapping sugarcane yellow leaf disease affected area using remote sensing technique. $J$. Sugarcane Res. 4:55-61.

Parmessur, Y., Aljanabi, S., Saumtally, S. and Saumtally, A. D. 2002. Sugarcane yellow leaf virus and sugarcane yellows phytoplasma: elimination by tissue culture. Plant Pathol. 51:561-566.

Pazhouhandeh, M., Dieterle, M., Marrocco, K., Lechner, E., Berry, B., Brault, V., Hemmer, O., Kretsch, T., Richards, K. E., Genschik, P. and Ziegler-Graff, V. 2006. F-box-like domain in the polerovirus protein $\mathrm{P} 0$ is required for silencing suppressor function. Proc. Natl. Acad. Sci. U. S. A. 103:1994-1999.

Peter, K. A., Liang, D., Palukaitis, P. and Gray, S. M. 2008. Small deletions in the Potato leafroll virus readthrough protein affect particle morphology, aphid transmission, virus movement and accumulation. J. Gen. Virol. 89:2037-2045.

Pinheiro, P. V., Kliot, A., Ghanim, M. and Cilia, M. 2015. Is there a role for symbiotic bacteria in plant virus transmission by insects? Curr. Opin. Insect Sci. 8:69-78.

Rao, G. P., Gaur, R. K., Singh, M., Srivastava, A. K., Virk, A. S., Singh, N., Viswanathan, R., Patil, A. S. and Jain, R. K. 2000. Occurrence of Sugarcane yellow leaf virus in India. Sugar Tech 2:37-38.

Rao, G. P., Gaur, R. K., Singh, M., Viswanathan, R., Chandrasena, G. and Dharamwardhaanhe, N. M. W. N. 2001. Occurrence of Sugarcane yellow leaf virus in India and Sri Lanka. Proc. Int. Soc. Sugar Cane Technol. 24:469-470.

Rassaby, L., Girard, J.-C., Lemaire, O., Costet, L., Irey, M. S., Kodja, H., Lockhart, B. E. L. and Rott, P. 2004. Spread of Sugarcane yellow leaf virus in sugarcane plants and fields on the island of Reunion. Plant Pathol. 53:117-125.

Rassaby, L., Girard, J.-C., Letourmy, P., Chaume, J., Irey, M. S., Lockhart, B. E. L., Kodja, H. and Rott, P. 2003. Impact of Sugarcane yellow leaf virus on sugarcane yield and juice quality in Reunion Island. Eur. J. Plant Pathol. 109:459-466.

Reinbold, C., Lacombe, S., Ziegler-Graff, V., Scheidecker, D., Wiss, L., Beuve, M., Caranta, C. and Brault, V. 2013. Closely related poleroviruses depend on distinct translation initiation factors to infect Arabidopsis thaliana. Mol. Plant-Microbe Interact. 26:257-265.

Ricaud, C. 1968. Yellow wilt of sugarcane in eastern Africa. Sugarcane Pathol. Newsl. 1:45-49.

Ricaud, C., Egan, B. T., Gillaspie, A. G. and Hughes, C. G. 2012. Diseases of sugarcane: major diseases. Elsevier, Amsterdam, The Netherlands. 412 pp.

Rochow, W. F. 1982. Dependent transmission by aphids of Barley 
yellow dwarf luteoviruses from mixed infections. Phytopathology 72:302-305.

Rodriguez-Medina, C., Boissinot, S., Chapuis, S., Gereige, D., Rastegar, M., Erdinger, M., Revers, F., Ziegler-Graff, V. and Brault, V. 2015. A protein kinase binds the C-terminal domain of the readthrough protein of Turnip yellows virus and regulates virus accumulation. Virology 486:44-53.

Rott, P., Bailey, R. A., Comstock, J. C., Croft, B. J. and Saumtally, S. 2000. D-CAS 1.2: a guide to sugarcane diseases. CIRADISSCT, CIRAD Publication Services, Montepellier, France.

Rott, P., Mirkov, T. E., Schenck, S. and Girard, J. C. 2008. Recent advances in research on Sugarcane yellow leaf virus, the causal agent of sugarcane yellow leaf. Sugar Cane Int. 26:1827.

Saitou, N. and Nei, M. 1987. The neighbor-joining method: a new method for reconstructing phylogenetic trees. Mol. Biol. Evol. 4:406-425.

Sanford, J. C. and Johnston, S. A. 1985. The concept of parasitederived resistance-deriving resistance genes from the parasite's own genome. J. Theor. Biol. 113:395-405.

Satyagopal, K., Sushil, S. N., Jeyakumar, P., Shankar, G., Sharma, O. P., Boina, D., Sain, S. K., Chattopadhyay, D., Asre, R., Kapoor, K. S., Arya, S., Kumar, S., Patni, C. S., Chattopadhyay, C., Pandey, A., Pachori, R., Thakare, A. Y., Basavanagoud, K., Halepyati, A. S., Patil, M. B. and Sreenivas, A. G. 2014. AESA based IPM package for Mustard. National Institute of Plant Health Management, Hyderabad, India. 49 pp.

Scagliusi, S. M. and Lockhart, B. E. L. 2000. Transmission, characterization, and serology of a Luteovirus associated with yellow leaf syndrome of sugarcane. Phytopathology 90:120-124.

Schenck, S. 1990. Yellow leaf syndrome: a new sugarcane disease. Hawaiian Sugar Planters Association, Honolulu, HI, USA. 98 pp.

Schenck, S., Hu, J. S. and Lockhart, B. E. L. 1997. Use of a tissue blot immunoassay to determine the distribution of Sugarcane yellow leaf virus in Hawaii. Sugar Cane 4:5-8.

Schenck, S. and Lehrer, A. T. 2000. Factors affecting the transmission and spread of Sugarcane yellow leaf virus. Plant Dis. 84:1085-1088.

Sharma, S. K., Meena, R. P., Pramesh, D., Kumar, S., Singh, T. S. and Baranwal, V. K. 2017. Nucleic-acid based techniques for the fine diagnosis of plant viruses in India. In: A century of plant virology in India, eds. by B. Mandal, G. P. Rao, V. K. Baranwal and R. K. Jain, pp. 621-686. Springer, Nature, Switzerland.

Singh, D., Tewari, A. K., Rao, G. P., Karuppaiah, R., Viswanathan, R., Arya, M. and Baranwal, V. K. 2009. RT-PCR/PCR analysis detected mixed infection of DNA and RNA viruses infecting sugarcane crops in different states of India: its phylogenetic relationships to closely related phytoplasmas. Sugar Tech 11:373-380.

Singh, J. and Singh, R. 2015. Sugarcane seed production: Indian scenario. J. Biotechnol. Crop Sci. 4:43-55.
Smith, G. R., Borg, Z., Lockhart, B. E. L., Braithwaite, K. S. and Gibbs, M. J. 2000. Sugarcane yellow leaf virus: a novel member of the Luteoviridae that probably arose by inter-species recombination. J. Gen. Virol. 81:1865-1869.

Spall, V. E., Shanks, M. and Lomonossoff, G. P. 1997. Polyprotein processing as a strategy for gene expression in RNA viruses. Semin. Virol. 8:15-23.

Tacke, E., Prufer, D., Salamini, F. and Rohde, W. 1990. Characterization of a potato leafroll luteovirus subgenomic RNA: differential expression by internal translation initiation and UAG suppression. J. Gen. Virol. 71:2265-2272.

Tamura, K., Stecher, G., Peterson, D., Filipski, A. and Kumar, S. 2013. MEGA6: molecular evolutionary genetics analysis version 6.0. Mol. Biol. Evol. 30:2725-2729.

Vega, J., Scagliusi, S. M. M. and Ulian, E. C. 1997. Sugarcane yellow leaf disease in Brazil: evidence for association with a Luteovirus. Plant Dis. 81:21-26.

Victoria, J. I., Avellaneda, M. C., Angel, J. C. and Guzman, M. L. 2005. Resistance to Sugarcane yellow leaf virus in Colombia. Proc. Int. Soc. Sugar Cane Technol. 25:664-669.

Viswanathan, R. 2002. Sugarcane yellow leaf syndrome in India: incidence and effect on yield parameters. Sugar Cane Int. 5:17-23.

Viswanathan, R., Alexander, K. C. and Garg, I. D. 1996. Detection of Sugarcane bacilliform virus in sugarcane germplasm. Acta Virol. 40:5-8.

Viswanathan, R. and Balamuralikrishnan, M. 2004. Detection of Sugarcane yellow leaf virus, the causal agent of yellow leaf syndrome in sugarcane by DAS-ELISA. Arch. Phytopathol. Plant Prot. 37:169-176.

Viswanathan, R. and Balmuralikrishnan, M. 2005. Impact of mosaic infection on growth and yield of sugarcane. Sugar Tech 7:61-65.

Viswanathan, R., Balamuralikrishnan, M. and Karuppaiah, R. 2006. Yellow leaf disease of sugarcane: occurrence and impact of infected setts on disease severity and yield. Proc. Sugar Cancer Technol. Assoc. India 67:74-89.

Viswanathan, R., Balamuralikrishnan, M. and Karuppaiah, R. 2008. Identification of three genotypes of Sugarcane yellow leaf virus causing yellow leaf disease from India and their molecular characterization. Virus Genes 37:368-379.

Viswanathan, R., Chinnaraja, C., Malathi, P., Gomathi, R., Rakkiyappan, P., Neelamathi, D. and Ravichandran, V. 2014. Impact of Sugarcane yellow leaf virus (ScYLV) infection on physiological efficiency and growth parameters of sugarcane under tropical climatic conditions in India. Acta Physiol. Plant. 36:1805-1822.

Viswanathan, R., Chinnaraja, C., Parameswari, B. and Chhabra, M. L. 2016. Status of yellow leaf resistance in sugarcane germplasm and parental clones at Sugarcane Breeding Institute, India. Int. Sugar J. 115:60-71.

Viswanathan, R., Jayanthi, R. and Sanakaranarayanan, C. 2017a. Integrated disease and pest management in sugarcane. Indian Farm. 67:28-32. 
Viswanathan, R., Karuppaiah, R. and Balamuralikrishnan, M. 2010. Detection of three major RNA viruses infecting sugarcane by multiplex reverse transcription-polymerase chain reaction (multiplex-RT-PCR). Aust. Plant Pathol. 39:79-84.

Viswanathan, R., Karuppaiah, R., Malathi, P., Kumar, V. G. and Chinnaraja, C. 2009. Diagnosis of Sugarcane yellow leaf virus in asymptomatic sugarcane by RT-PCR. Sugar Tech 11:368-372.

Viswanathan, R., Malathi, P. and Neelamathi, D. 2018. Enhancing sugarcane yield per hectare through improved virus-free seed nursery programme. ICAR News 24:4-5.

Viswanathan, R., Nithya, K., Parameswari, B., Jeevalatha, A. and Rao, G. P. 2017b. The current status of Luteovirus and Polerovirus research in India. In: A century of plant virology in India, eds. by B. Mandal, G. P. Rao, V. K. Baranwal and R. K. Jain, pp. 285-305. Springer, Nature, Switzerland.

Viswanathan, R., Padmanaban, P., Mohanraj, D., Sundar, A. R. and Premachandran, M. N. 1999. Suspected yellow leaf syndrome in sugarcane. Sugarcane Breed. Inst. Newsl. 18:2-3.

Viswanathan, R. and Rao, G. P. 2011. Disease scenario and management of major sugarcane diseases in India. Sugar Tech 13:336-353.

Wang, M. Q., Xu, D. L., Li, R. and Zhou, G. H. 2012. Genotype identification and genetic diversity of Sugarcane yellow leaf virus in China. Plant Pathol. 61:986-993.

Wang, M.-Q. and Zhou, G.-H. 2010. A near-complete genome sequence of a distinct isolate of Sugarcane yellow leaf virus from China, representing a sixth new genotype. Virus Genes 41:268-272.

Wei, C., Hincapie, M., Larsen, N., Nuessly, G. and Rott, P. 2016. First report of Sugarcane yellow leaf virus infecting grain sorghum (Sorghum bicolor) in the United States. Plant Dis. 100:1798.

White, W. H., Reagan, T. E. and Hall, D. G. 2001. Melanaphis sacchari (Homoptera: Aphididae), a sugarcane pest new to Louisiana. Fla. Entomol. 84:435.

Xie, Y., Wang. M., Xu, D., Li, R. and Zhou, G. 2009. Simultaneous detection and identification of four sugarcane viruses by one step RT-PCR. J. Virol. Methods 162:64-68.

Yan, S.-L., Lehrer, A. T., Hajirezaei, M. R., Springer, A. and Komor, E. 2009. Modulation of carbohydrate metabolism and chloroplast structure in sugarcane leaves which were infected by Sugarcane yellow leaf virus (SCYLV). Physiol. Mol. Plant Pathol. 73:78-87.

Yang, X., Sood, S., Glynn, N., Islam, M. S., Comstock, J. and Wang, J. 2017. Constructing high-density genetic maps for polyploid sugarcane (Saccharum spp.) and identifying quantitative trait loci controlling brown rust resistance. Mol. Breed. 37:116.

Yang, X., Sood, S., Luo, Z., Todd, J. and Wang, J. 2019. Genomewide association studies identified resistance loci to orange rust and yellow leaf virus diseases in sugarcane (Saccharum spp.). Phytopathology 109:623-631.

Yang, Z. 2007. PAML 4: phylogenetic analysis by maximum likelihood. Mol. Biol. Evol. 24:1586-1591.

You, Q., Yang, X., Peng, Z., Islam, M. S., Sood, S., Luo, Z., Comstock, J., Xu, L. and Wang, J. 2019. Development of an Axiom Sugarcane100K SNP array for genetic map construction and QTL identification. Theor. Appl. Genet. 132:28292845.

Zhang, Y.-L., Xiong, G.-R., Wang, J.-H., Zhang, S.-Z., Guan, M.H., Yang, W.-J. and Liu, Z.-X. 2011. Construction of ihpRNA expression vector of Sugarcane yellow leaf virus $\mathrm{CP}$ protein gene and genetic transformation in tabacco. Bull. Bot. Res. 31:537-542.

Zhou, G., Li, J., Xu, D., Shen, W. and Deng, H. 2006. Occurrence of Sugarcane yellow leaf virus in South China and its transmission by the sugarcane-colonising aphid, Ceratovacuna Lanigera. Sci. Agric. Sin. 39:2023-2027.

Zhu, Y. J., Lim, S. T. S., Schenck, S., Arcinas, A. and Komor, E. 2010. RT-PCR and quantitative real-time RT-PCR detection of Sugarcane yellow leaf virus (SCYLV) in symptomatic and asymptomatic plants of Hawaiian sugarcane cultivars and the relation of SCYLV to yield. Eur. J. Plant Pathol. 127:263273.

Zhu, Y. J., McCafferty, H., Osterman, G., Lim, S., Agbayani, R., Lehrer, A., Schenck, S. and Komor, E. 2011. Genetic transformation with untranslatable coat protein gene of Sugarcane yellow leaf virus reduces virus titter in sugarcane. Transgenic Res. 20:503-512.

Zuckerkandl, E. and Pauling, L. 1965. Evolutionary divergence and convergence in proteins. In: Evolving genes and proteins, eds. by V. Bryson and H. J. Vogel, pp. 97-166. Elsevier Academic Press, New York, NY, USA. 